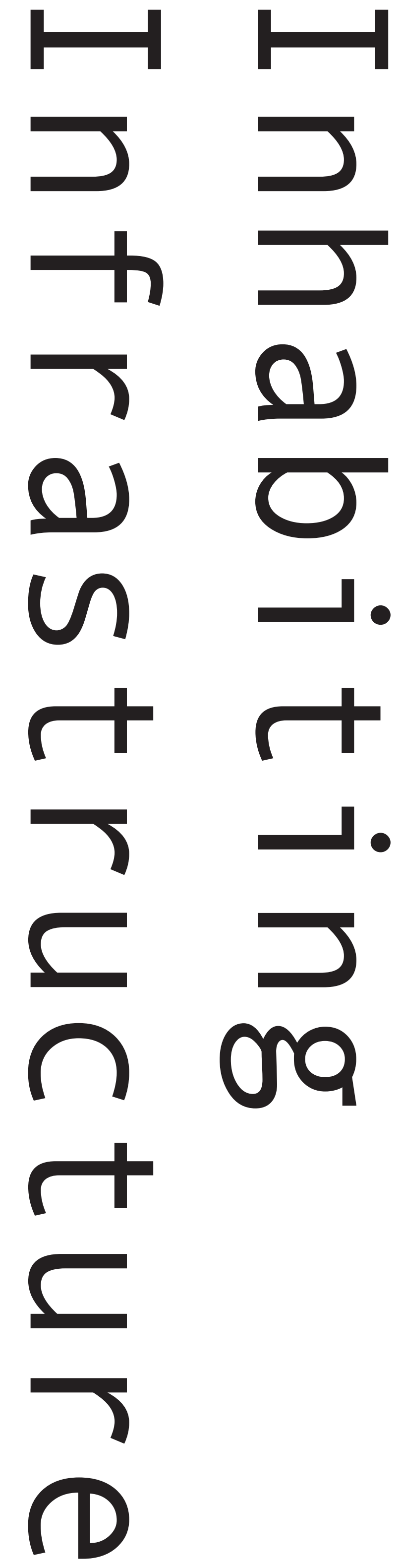




\section{Inhabiting Infrastructure}

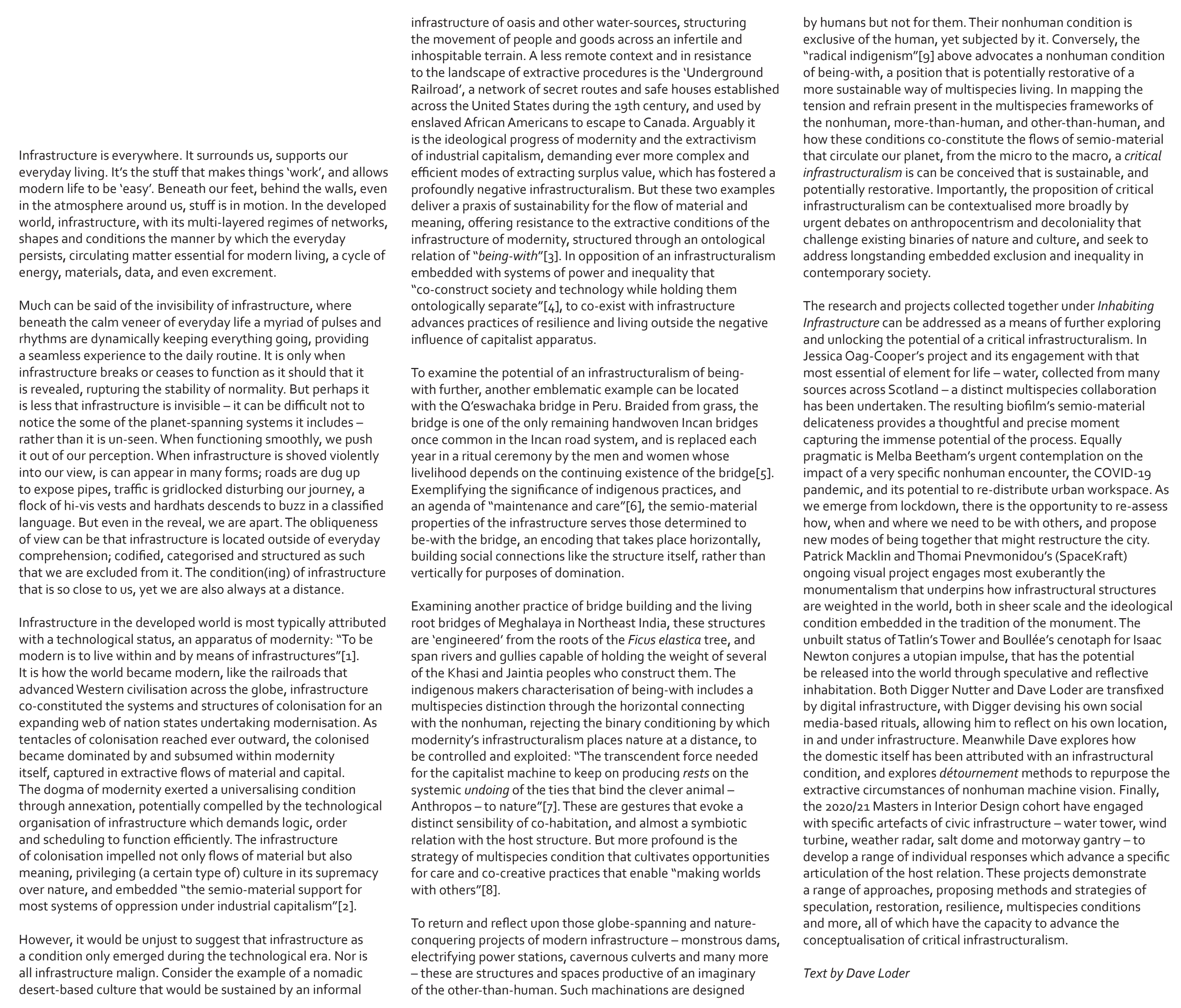




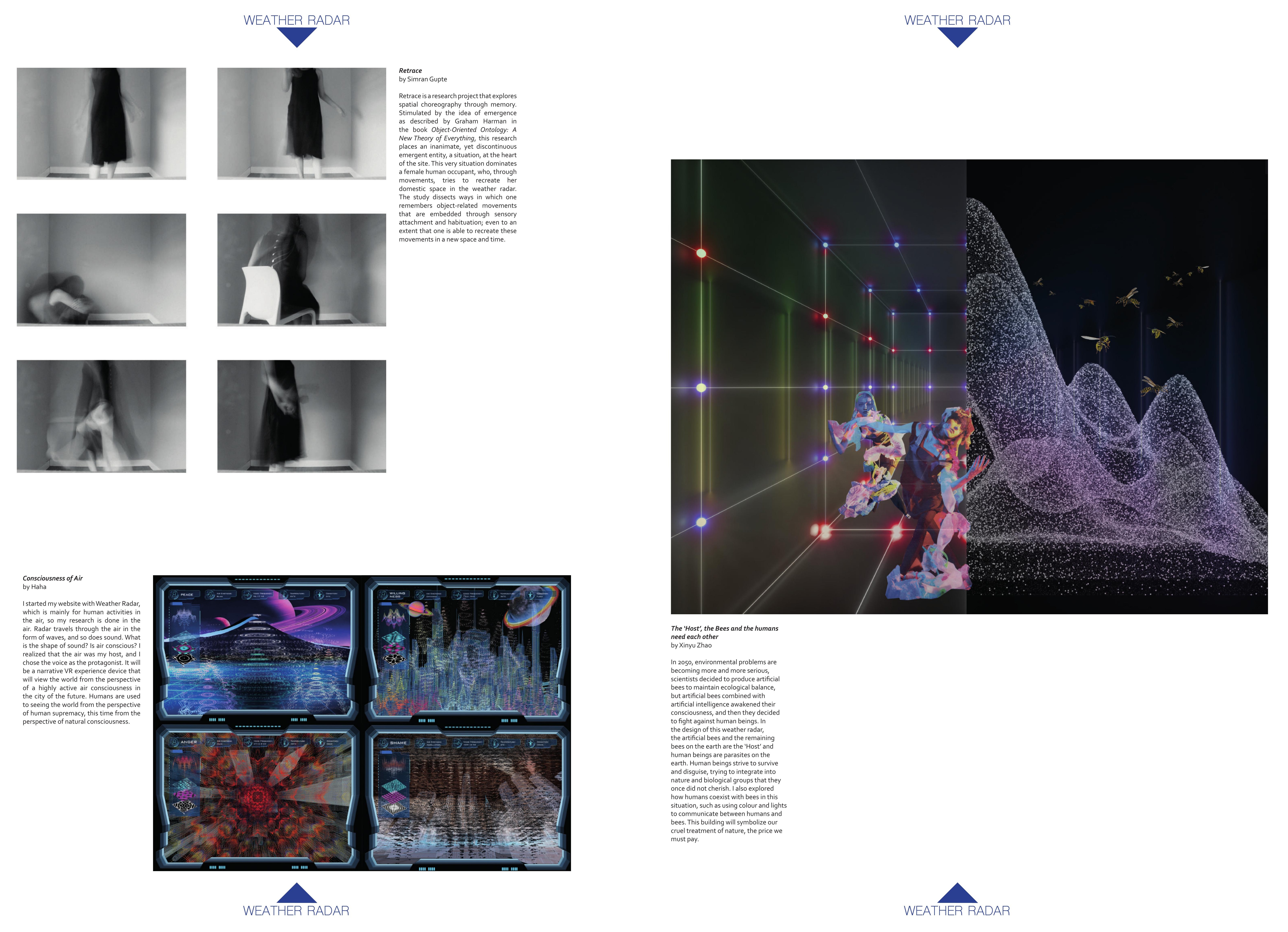



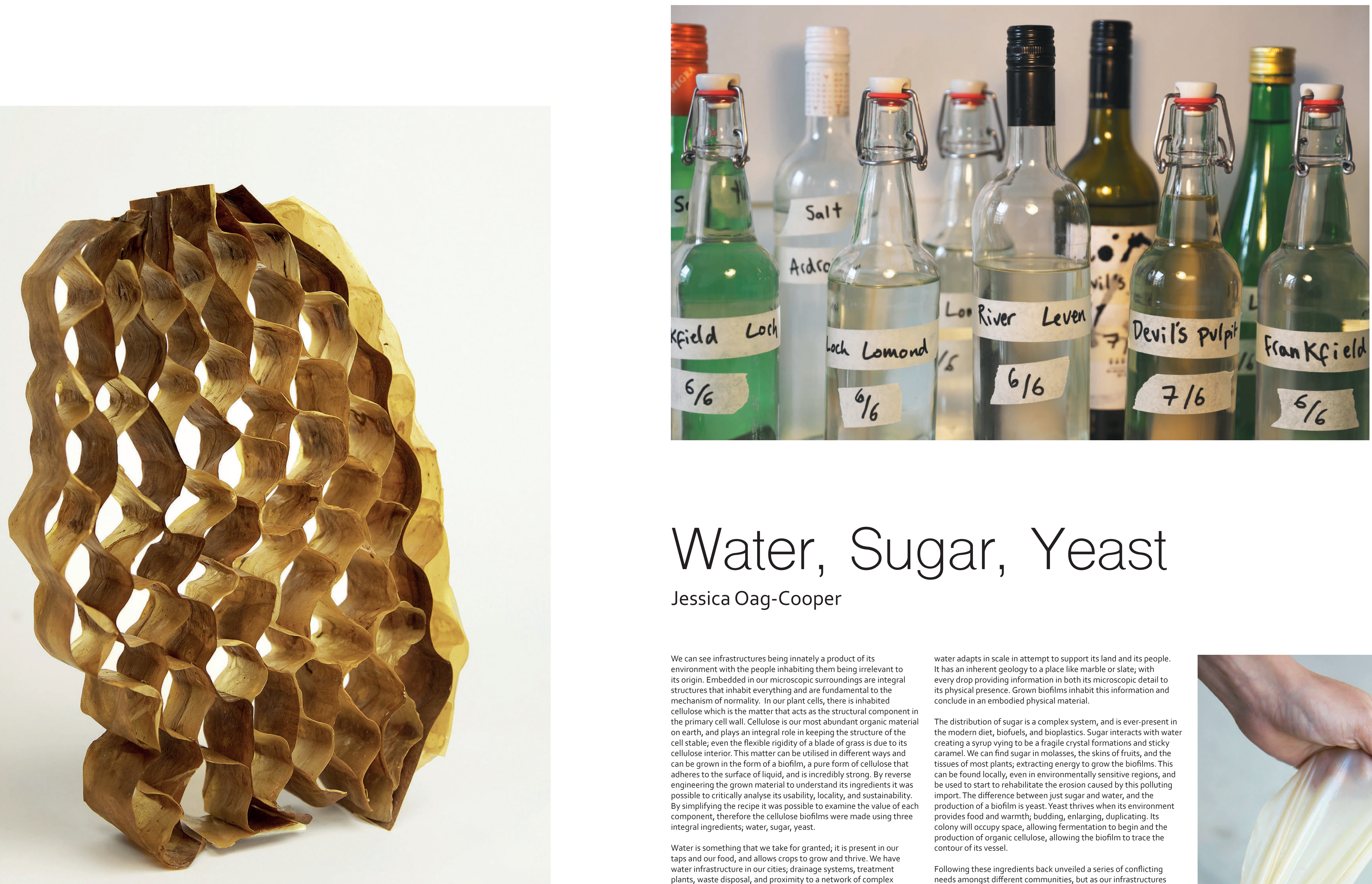

\section{Water, Sugar, Yeast} Jessica Oag-Cooper
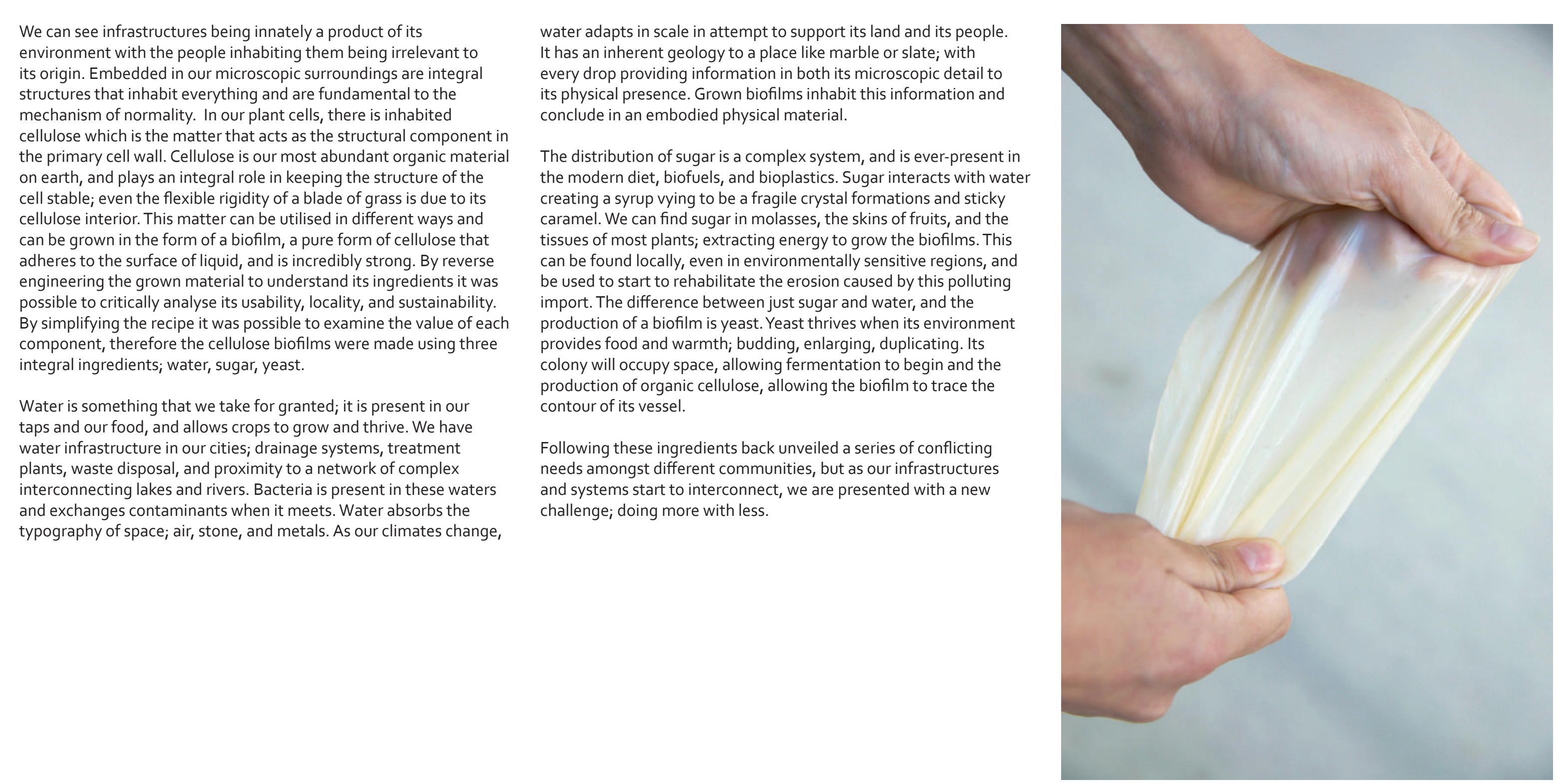


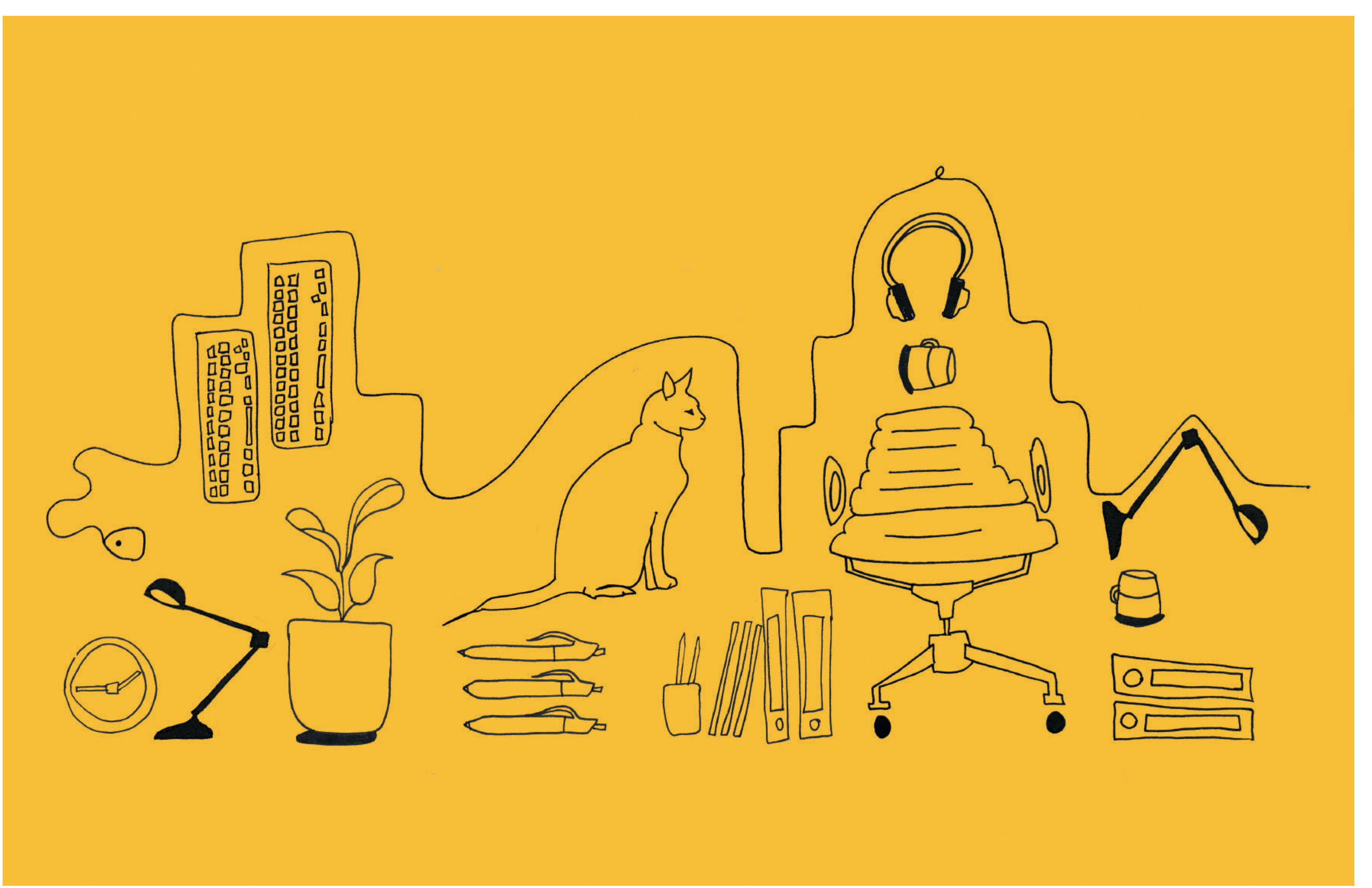

\section{Rebuilding The City Around Hybrid Work}

Melba Beetham
Remote working has impacted the lifestlye of the desk-based
professional in the last year and prompted a comparison of the

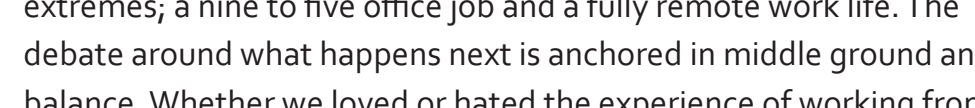
balance. Whether we loved or hated the experience of working from
home in the pandemic, distributed work post lockdown promises to be a very different thing; a society now experienced a tremote

There are many facets to the discussion about the new workplace
yett he nucleus what the job is, it's hard to get away from the workstation's basc requirements; a desk, a chair, a power socket, a little circulation
in all, a rectangular block of two to three square metres.

This component moved overnight from its base at the office to the
home as if by flying carpet. The real estate requirement hadn't gone landed on the kitchen table or in thice between work and home became a tangled mess. And yet, evidence
has now gathered to suggest that the model has numerous benefits The gains aren't just practical such as the lack of commute, but psychological. The pressure to be seen to be working, and even

increased trust. Feling trusted to deliver is good for seftcc and builds better relationships. It also can help organisations to be more efretwe

"A trust-based work culture has two major benefits: One, which people may not suspect, is productivity. As long as everyone is clear
on the vision, people can be left to get on with their work. Tasks beneffit is speed because everyone doesn't have to be involved $w$
everenthing Together the increased productivity and speed that everything. Together, the increased productivity and speed that
come out of a trust culture mean that organisations can get so mus

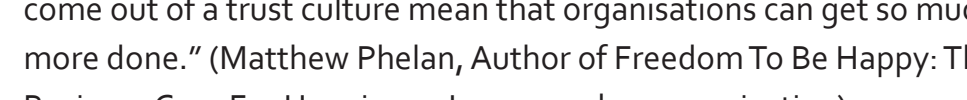
Business Case For Happiness. In personal communication)

With employers having gathered evidence that workers can
deliver remotely, the typical workinin week is under review. Mary organisations move to a hybrid model, with remote working offered
at least part of the week. The task organisations face is balancing the advantages of remote working with the challenges.

The countemeight to increased hexbility and freedom is lost fochs Missed opportunities for collaboration and, most insidiousyly, the risis
of isolation." [1] As options other than one's own home become available, workers dol want to work?'? We turn to co-working spaces to provide
remote non-domestic workspace have primarily scooped up free-lancers and small companies. This itime around, digtita nomads of arge organisisations. This option Retworking opportunities, expanding social connections, which

Even the term co-working space becomes increasingly expansivive. beth civic and con mercial spaces absorb the activity of work with hospitality venves not only accommodating people who wish to work but tiviting them. Citizen $M$ Glasgow offers access

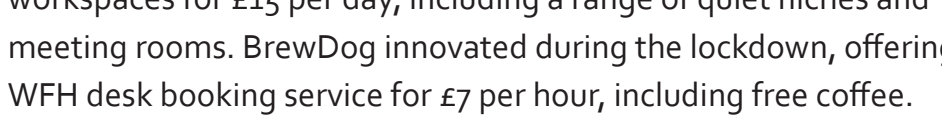

As well as having an effect on public spaces, distributed work has a Apple fefect on in infastructure on a large scale. In a Financial Times described how WFH may change the rolo of coities, with around 40 ire space likely to be released.

Living in cities is going to become an altogether different

lappens to property prices, and that a citicicl consideration in 1 this the conversion of office space to or residential space is something
that's going to take place in number of the big cities of the wordd"

In personal communication Michael added

.released office space if properly packaged into not-too-big
residential units will providea a perfect entry point for the younger generation seekng to get onto the bottom rung of the property

This paints a dy

Rural areas could also change as a result of this movement. The lish government have laid plans to create a network of 400 remole working hubs acrosss the country. The project intends to improve reducing commuting. The intention is to repopulate rural areas.

With this wave of changes across the world, what happens to the Uffice? I sthere even an offcce? The conversation is mainly going
the direction offes, probably,y but with a different emphasis.

With workers sharing physical space less often, the redefined offee teamwork

"Workplaces are being reimagined for activities beneffing from face-tof-face interaction, including collaboratition on projects and dentity." "[4]

More fluid and social spaces are looking likely. The workstation footprint will b e cut down dramatically, and permanent desks giviva
way to hotdesking. This will require careful planning of logistics get the capacty well matched to the number of available spaces.

Vitra has captured the redefinition with The Club office concept, office - from being a place of productivity, the office becomes a place

Workplaces may borrow the language of other interiors more in sciable and domestic interiors to make them feel comfortable. Ve, the definition of workplace needs to be carefully maintained online and IRL meeting rooms si likely to flourish. Booth for video pecome the signature of an organisation.

The changes offer a nopportunity to scrutinise the interior, checking sthe primary yurpose of a given space concentration and quiet work or conversation and social engagement?

David Dewane's Eudaimonia (Human Flourishing) machine, an experimental laboratory space in which spaces are defined intensely

Whistils prident to develop spaces for better output, let's not Jirget that the workplace isn't only about productivity.At least not organisations also comes from the serendipititus. "Not being able to workin the studio, bounce off each other, have developing can be challenging. Meeting with other colleagues in the Studio kitchen to get a corfee or looking over someone's shoulder heseut things are missed." "Roisin Reilly. Associtete, B3 Designers. In personal communication

These incidental aspects of the working day help explain why ther may bee mixee bag of emotions in losing the established office

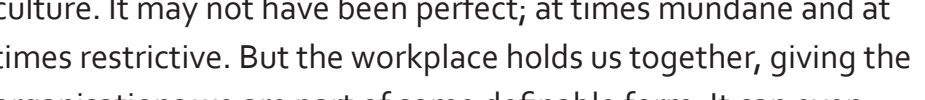

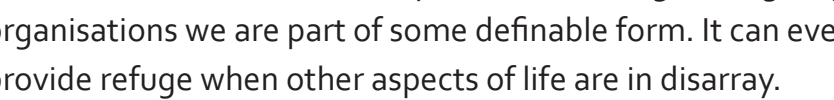

The redeffinition of workplace culture and the spaces we work in is bound to be a steep learning curve. As things settle into a new shape, te may have more precise model so f success, bits

The first day in a new job could have a very different feel. Where iypically you are sthow to your desk, and from there you learn how

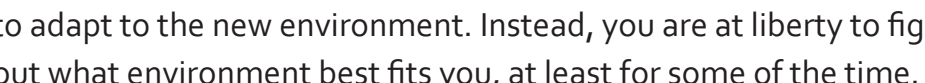
The working week is becoming more personally tailiored.

As we move into a new era for workplace cutture and consequentt redesign, the choices opening up to people are exciting. They offer
empowerment to the individual and could well spark eudaimonia at the very least, a little more wellhess in the working dar

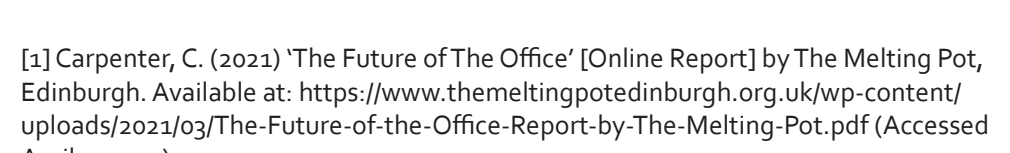

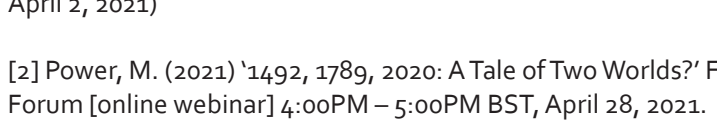

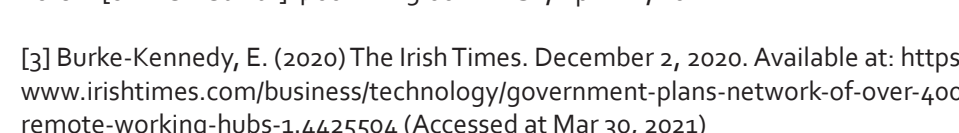

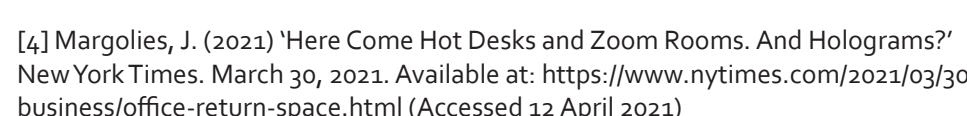

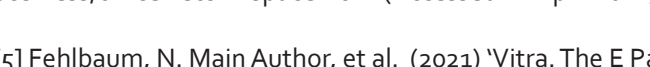

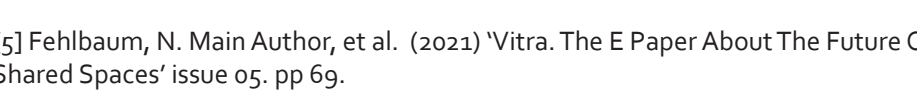

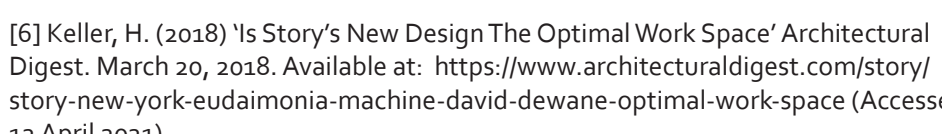




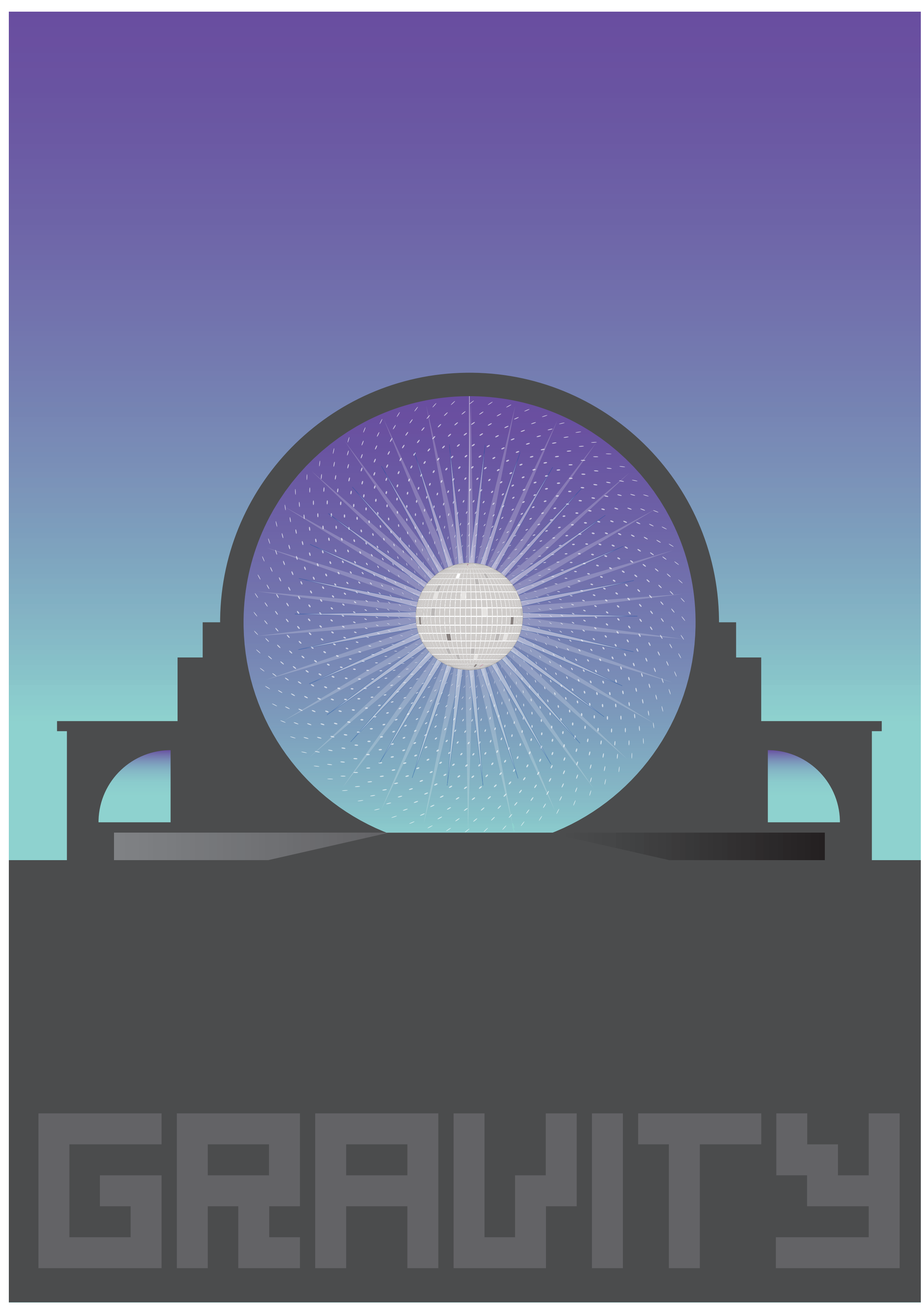

The Mirrorball and the Deckchair
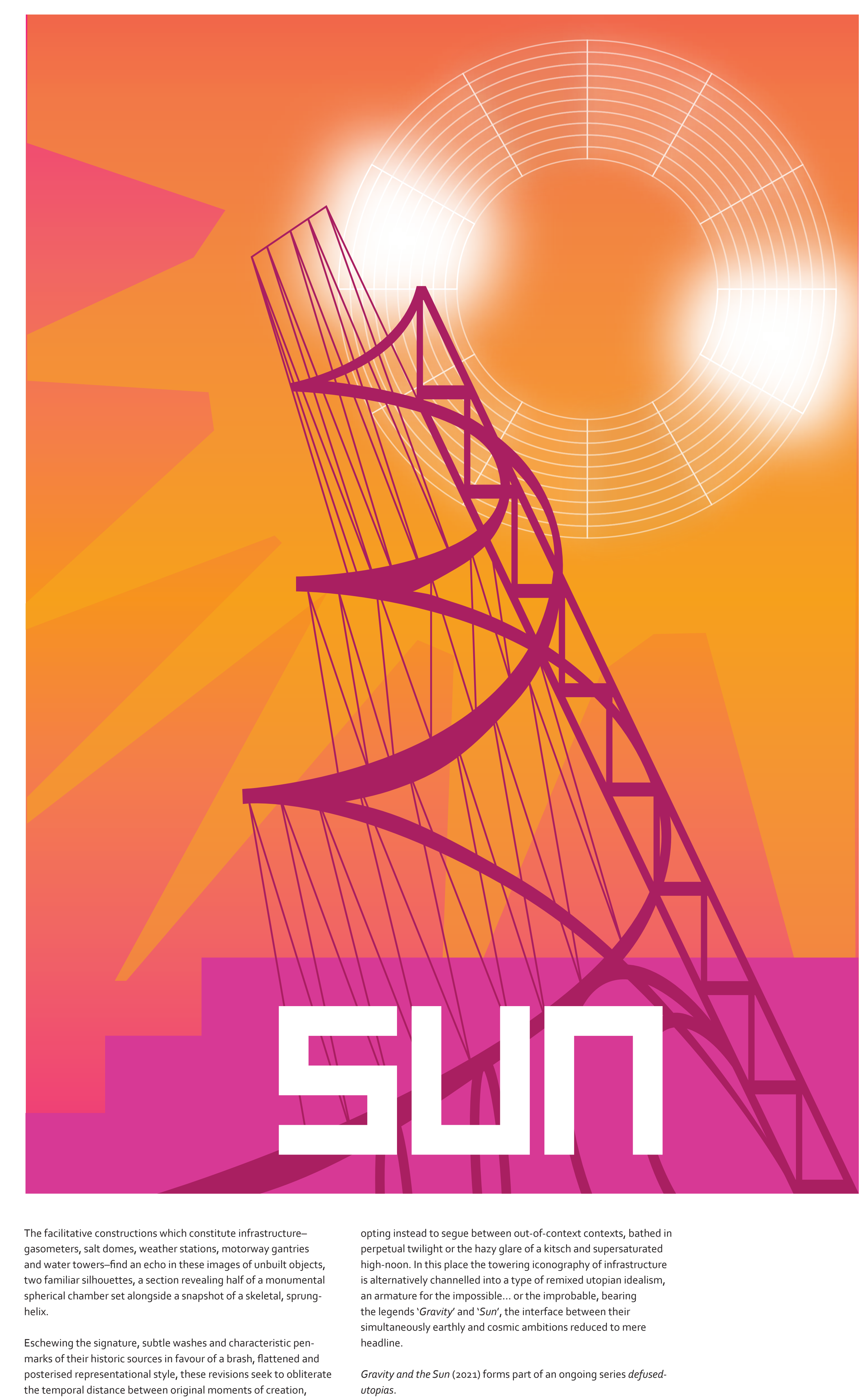

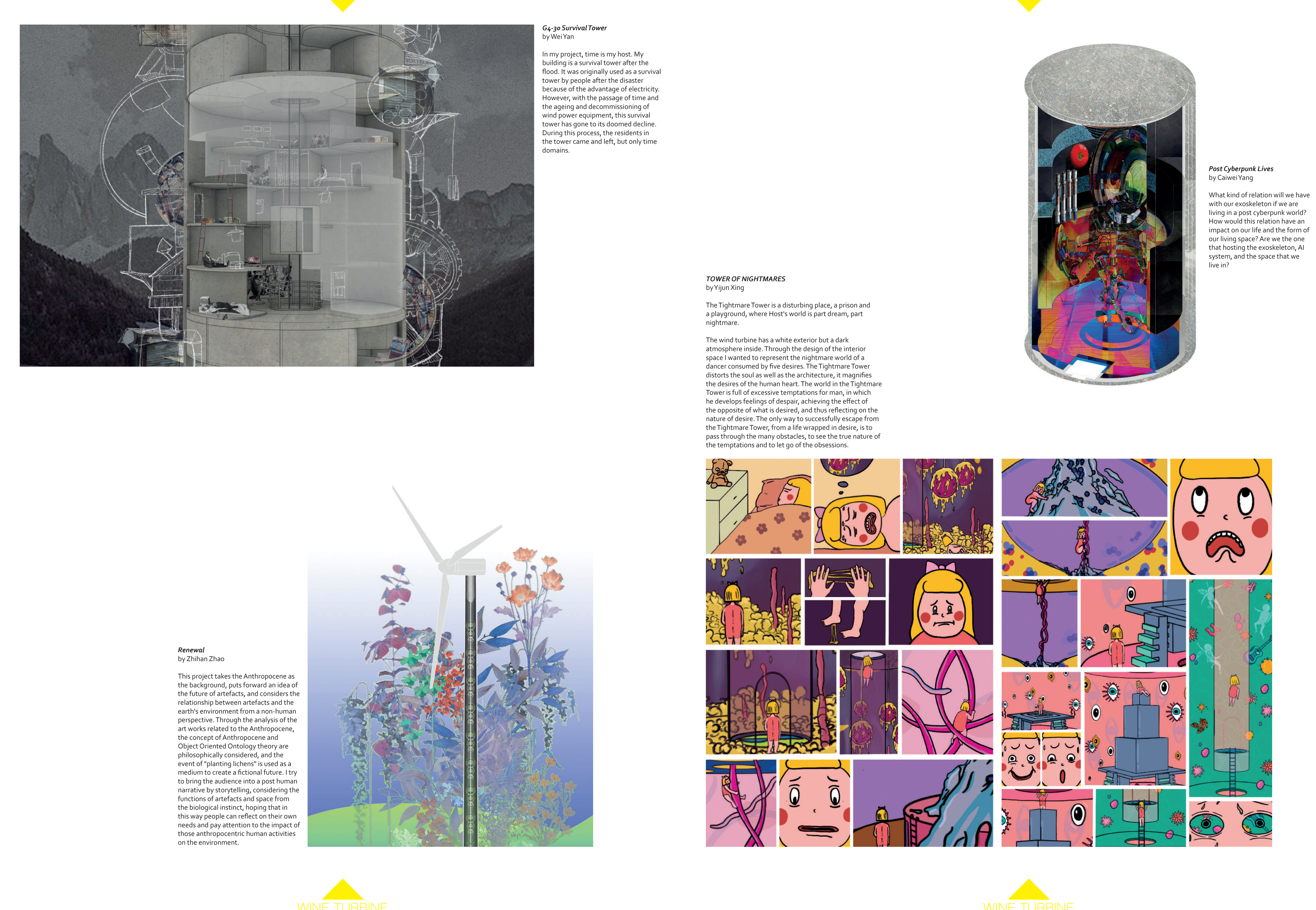

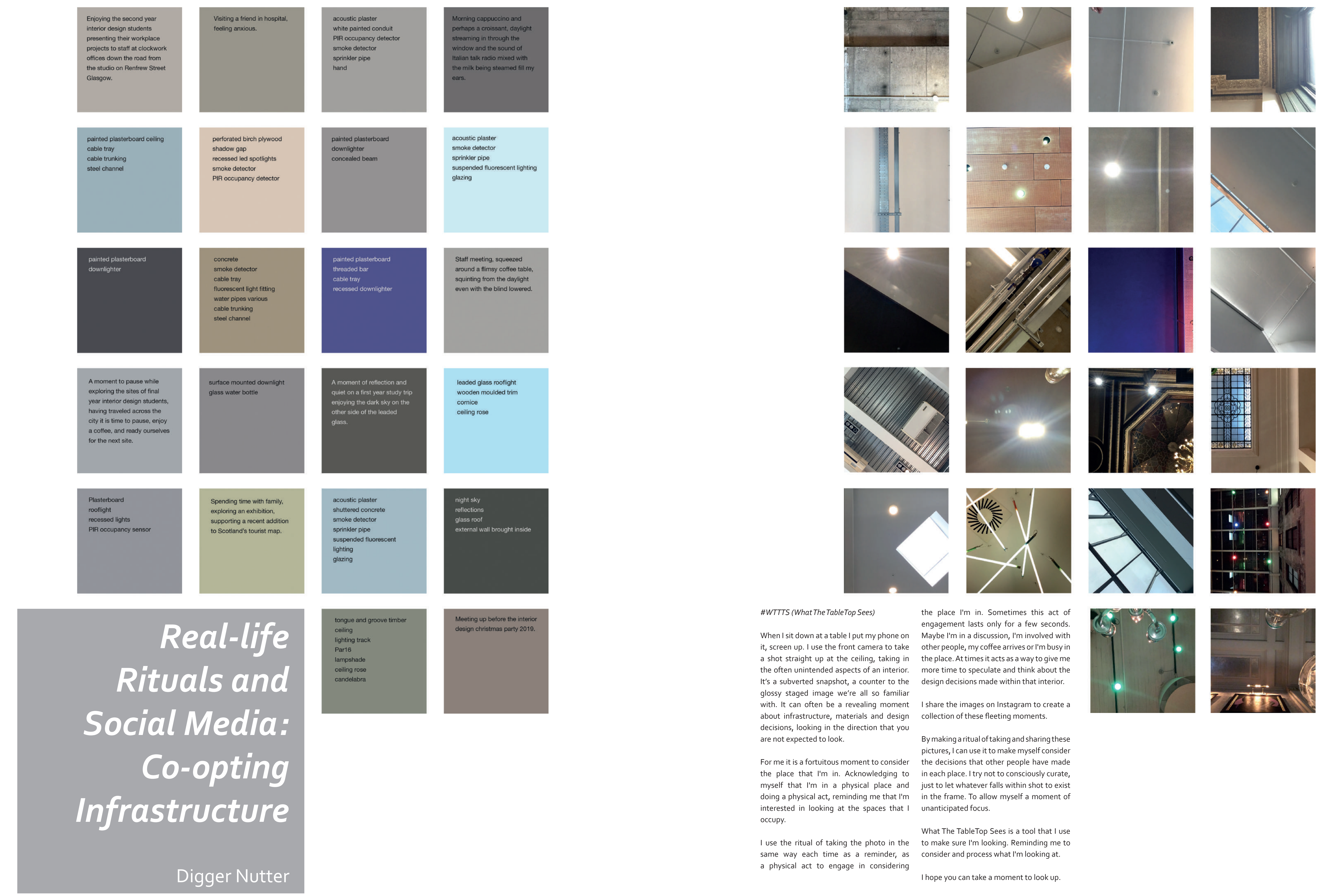

\#WTTTS (What The TableTop Ses)

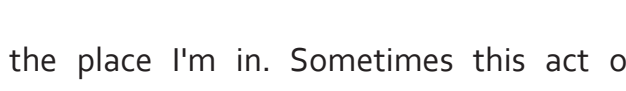
When I Ist down nat table l put my phone on Maybe I'm in a discussion, 'I' involved with

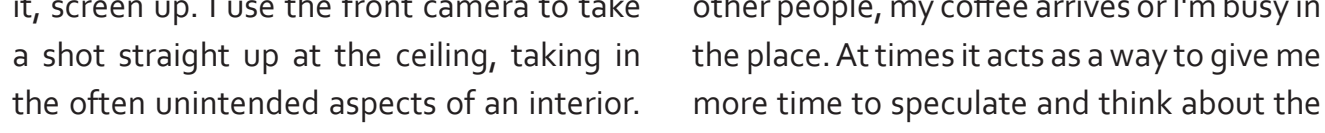

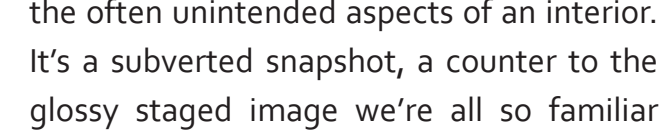
with. It can often be a revealing moment
about infrastructure, materils and desigi collection of these f fleting moments.

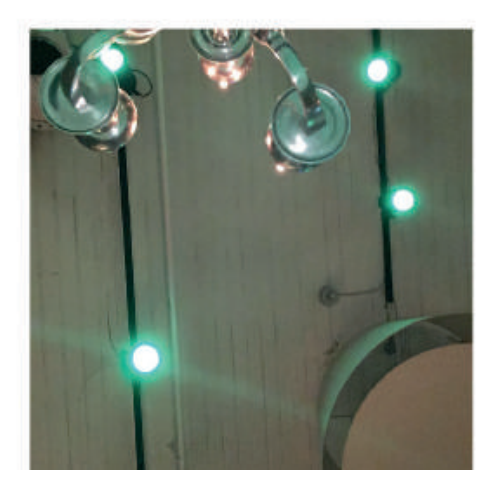
प्रांता Bymakngantulualoftakingand sharingthes
pictures, lcan useit to make myself consider the place that im in - Acknowledging to in each place Itry not to consciously curate myself that I' $m$ in a physical place and just to let whatever falls within shot to exis interested in looking at the spaces that 1 unanticipated focus

What The Table Top Sees is a tool that I U same way each time as a reminder, as consider and process what " $m$ looking at. a physical act to engage in considering 


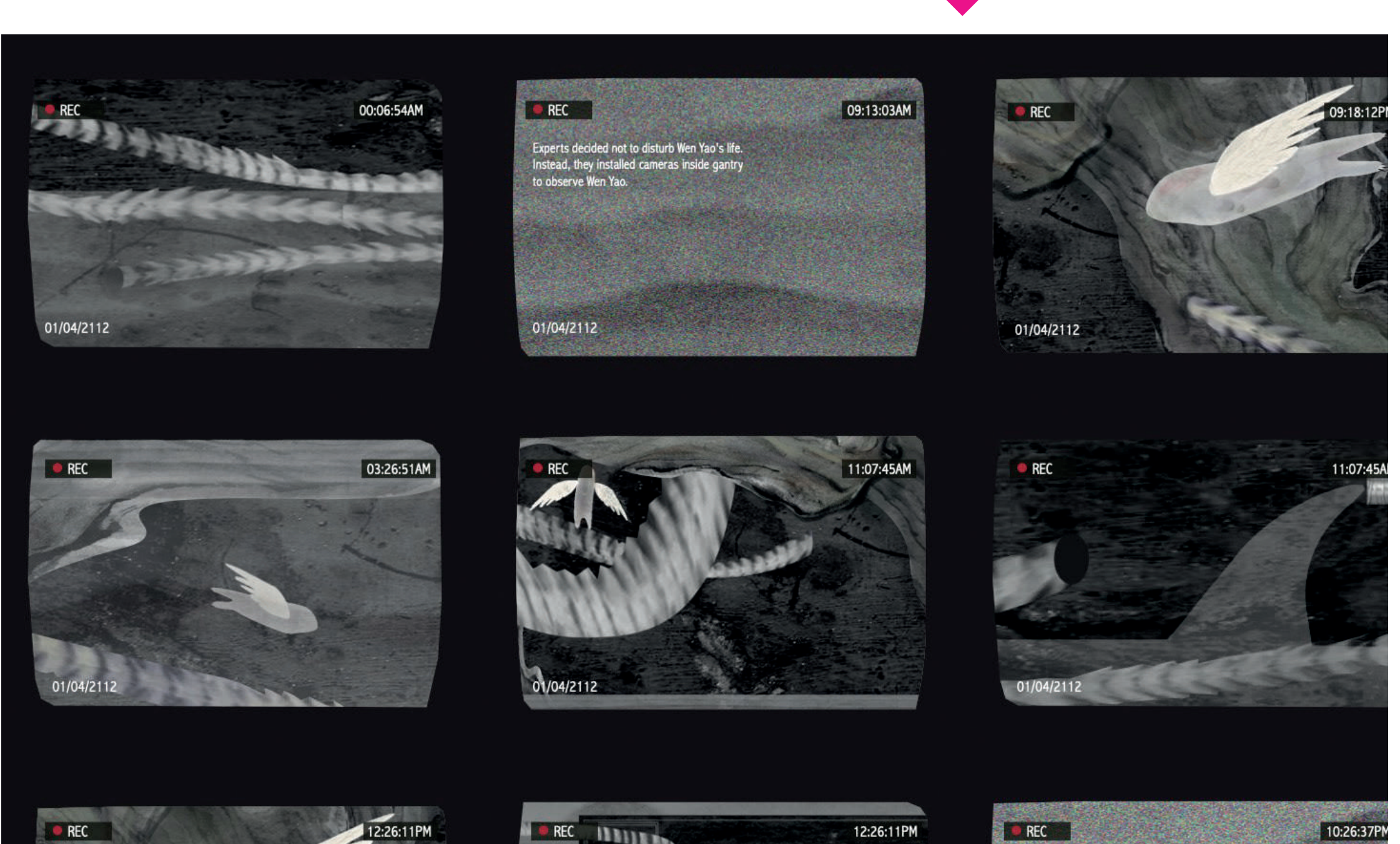

Shanh hijng of the Weraring States
period, which is the oldest book of
myths sand legendsin

the Tang Dynasty, they disappeared,
because they had been hunted and

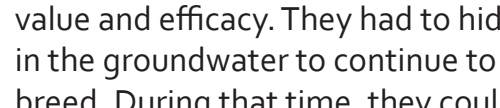

only feed on industrial waste. Until
2033, groundwater reduction, Wen Yao

reappear on the land. At the same time
people use motorway gantry to add

the tunction of stotoring and purtifing

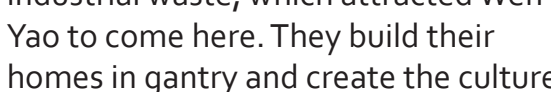

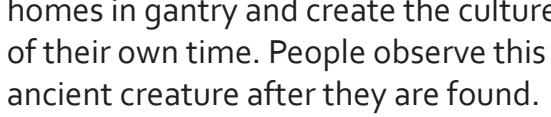

This project discusses the fision and
confict between Chinese tradtional

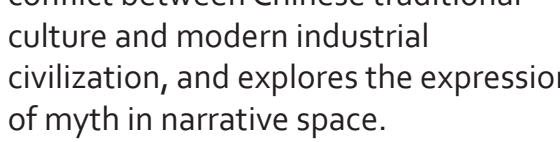

office of Synesthesia- Sense Loading

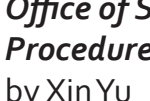
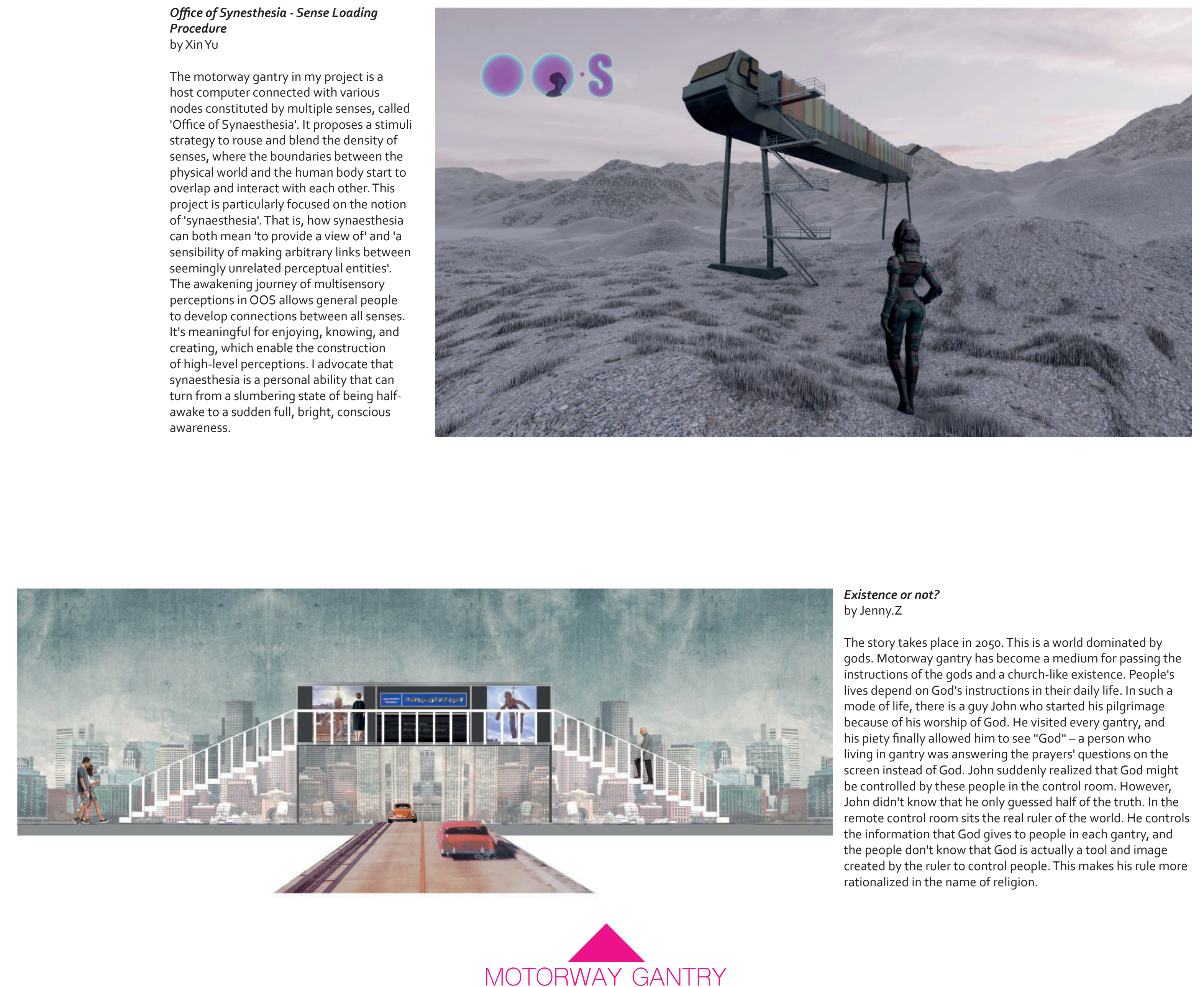

Existence or not?
by Jenyyz

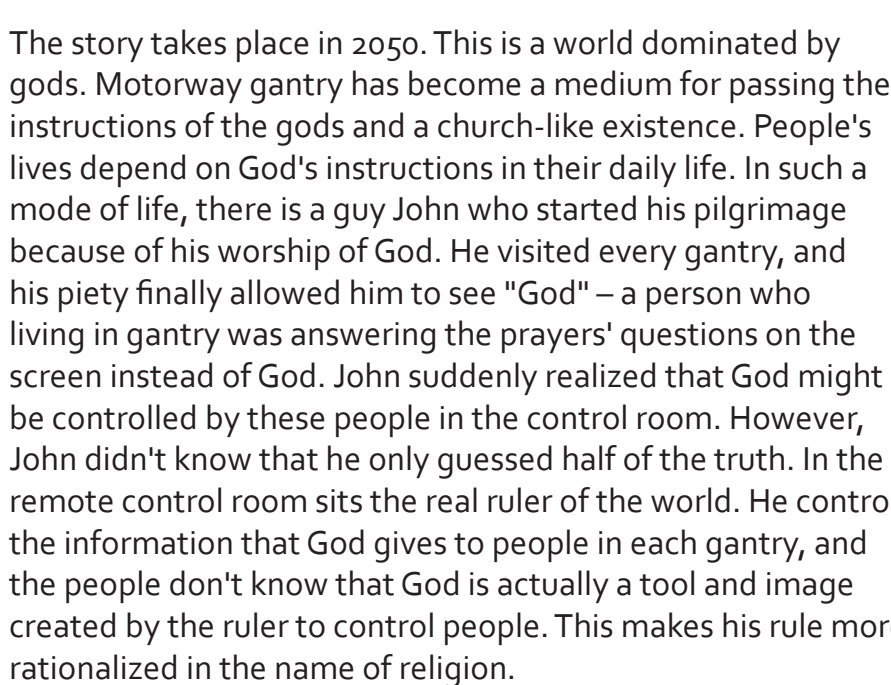

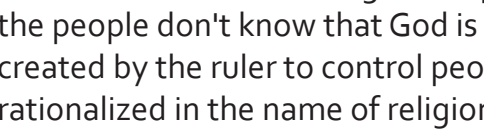

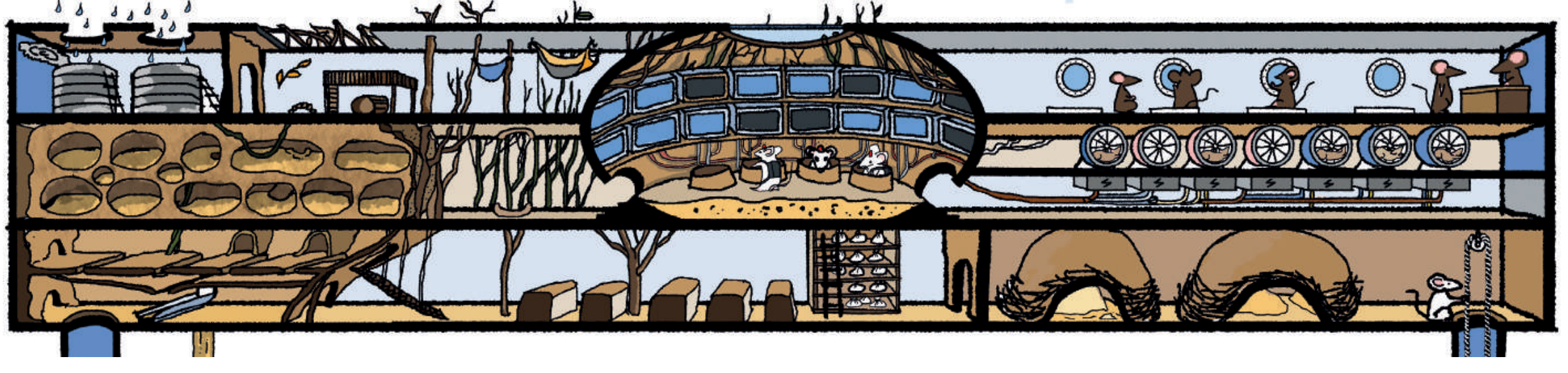

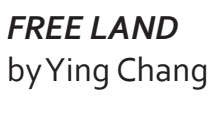

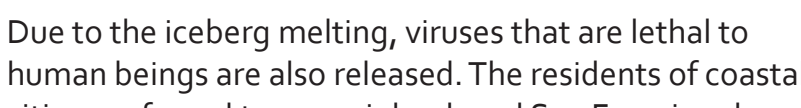
become an emprytycty. During the evacuation, two cages

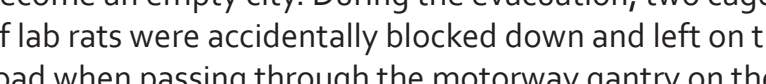

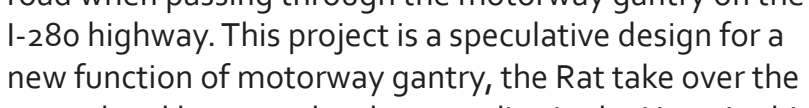

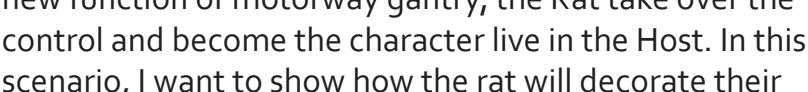

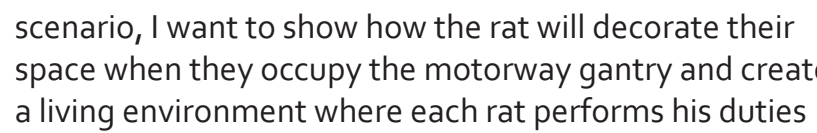

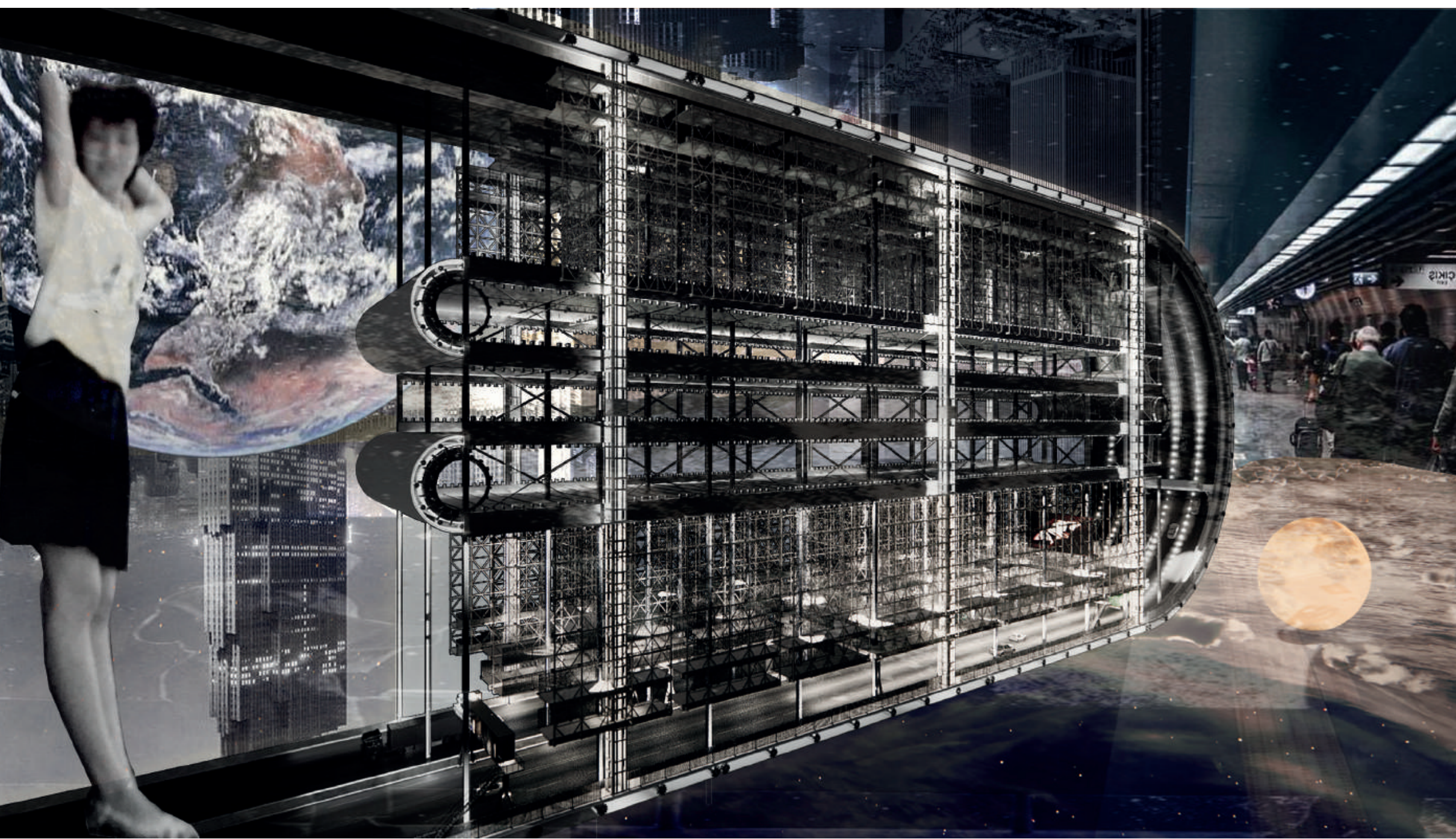

Endless verse
byywonder

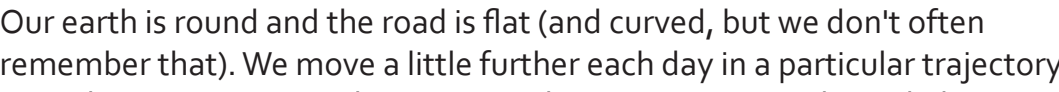

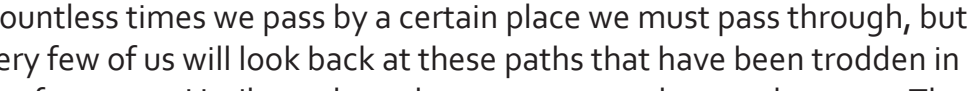

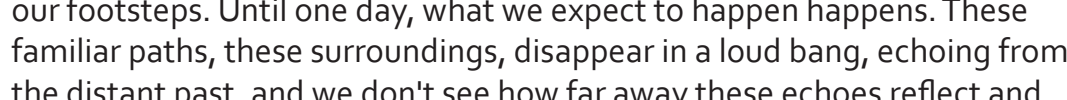

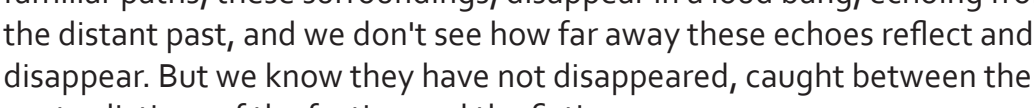

contradictions sof the fraction and the fiction. 

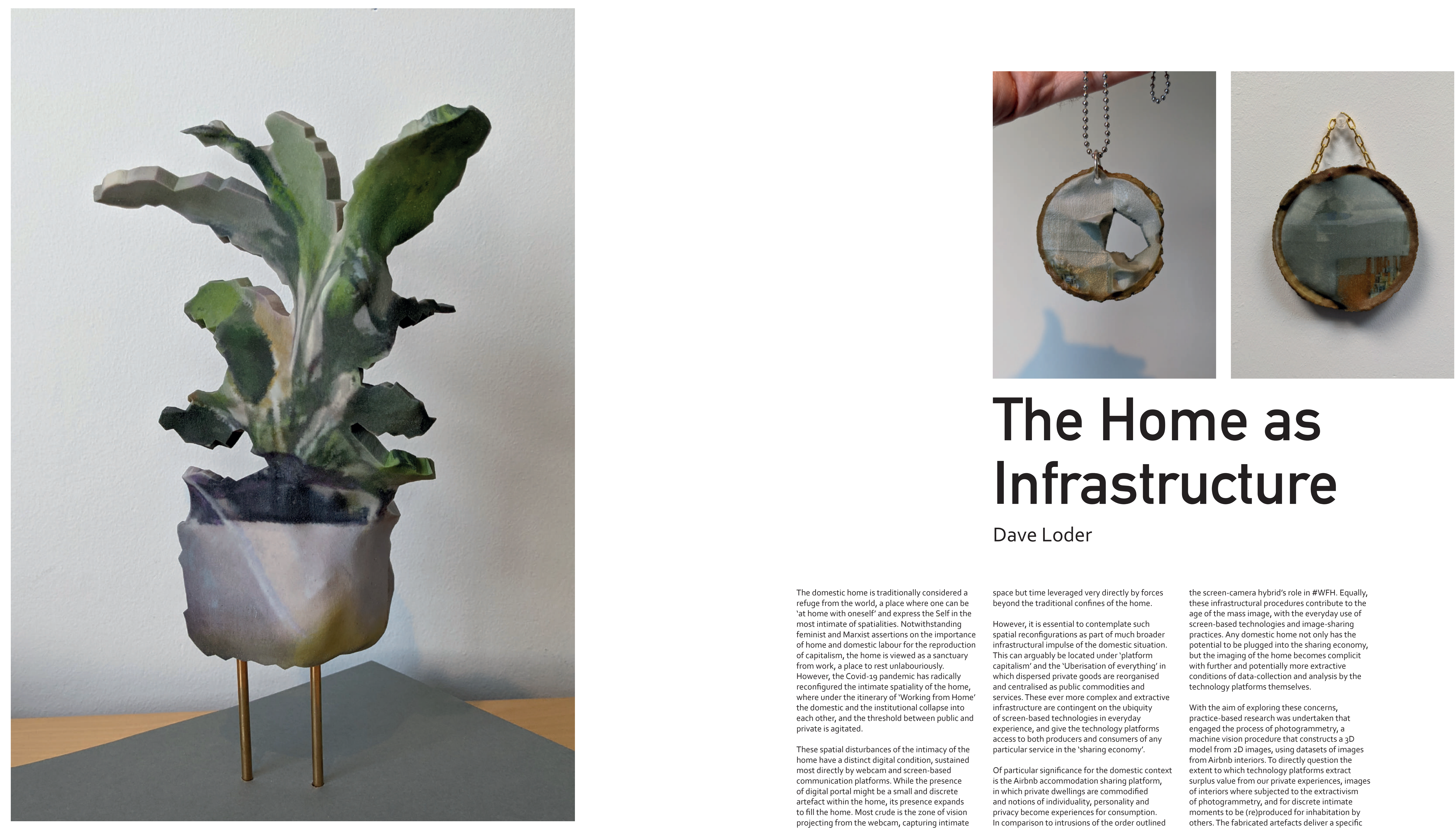

\section{The Home as Infrastructure}

Dave Loder
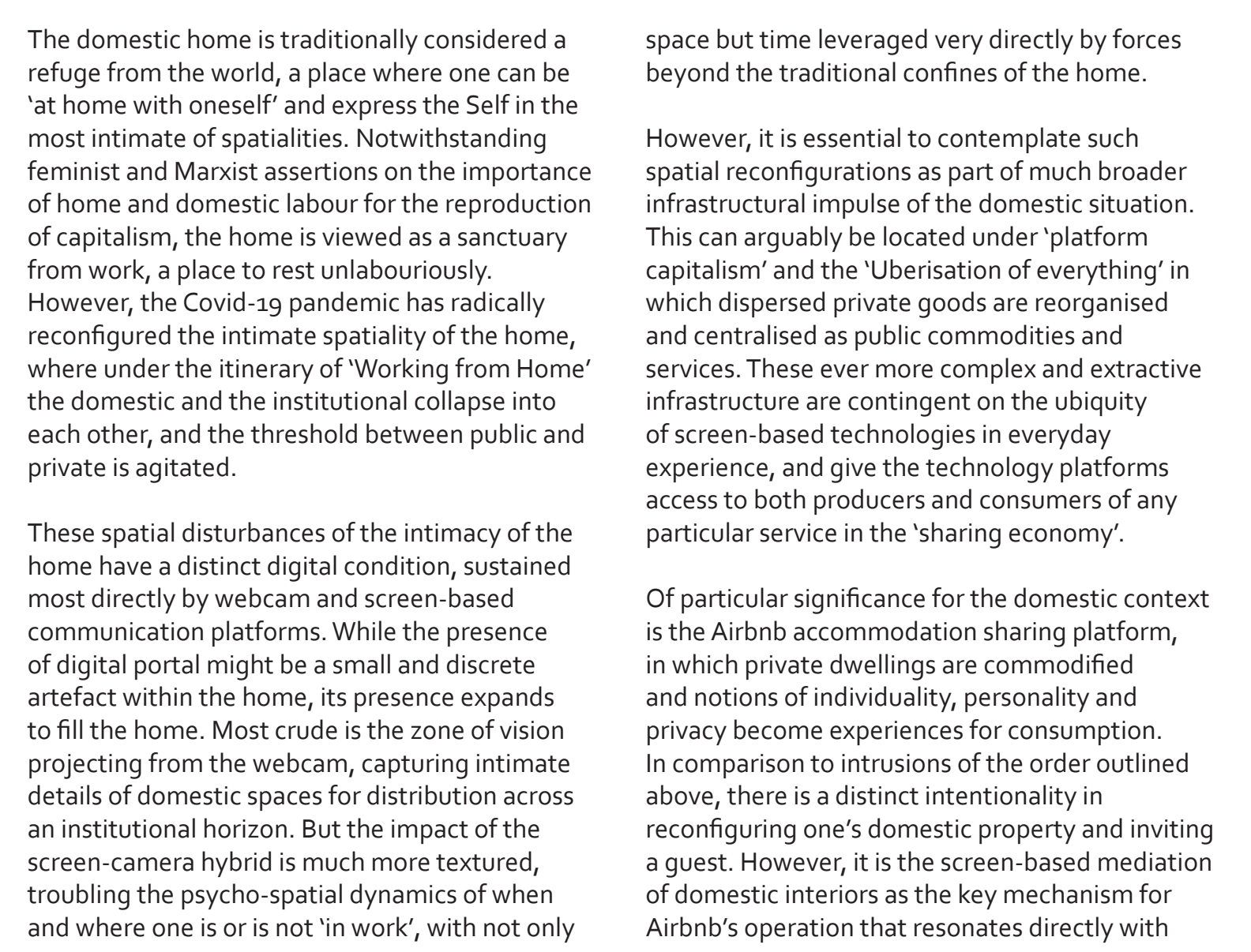

the screen-camera hybrid's role in \#WWHH. Equally,
these infastraturutural procoedures contributet to the tat

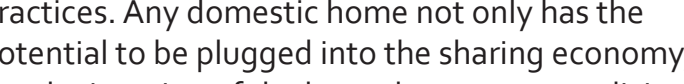
Wut the imaging of the home becomes complictit

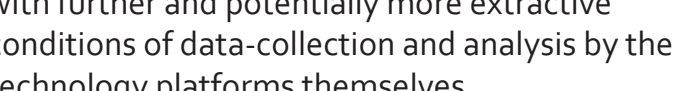

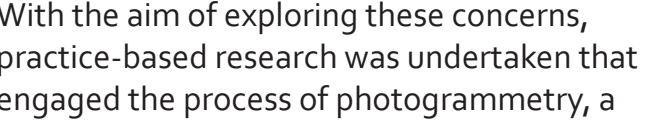

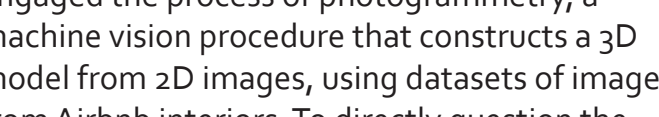

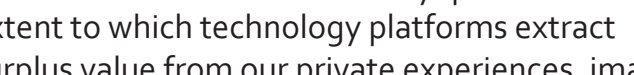
Miors where subjected to the extractivism

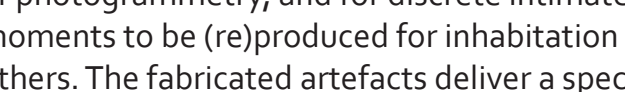

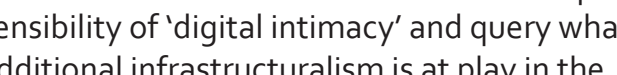
domesticinterior. 


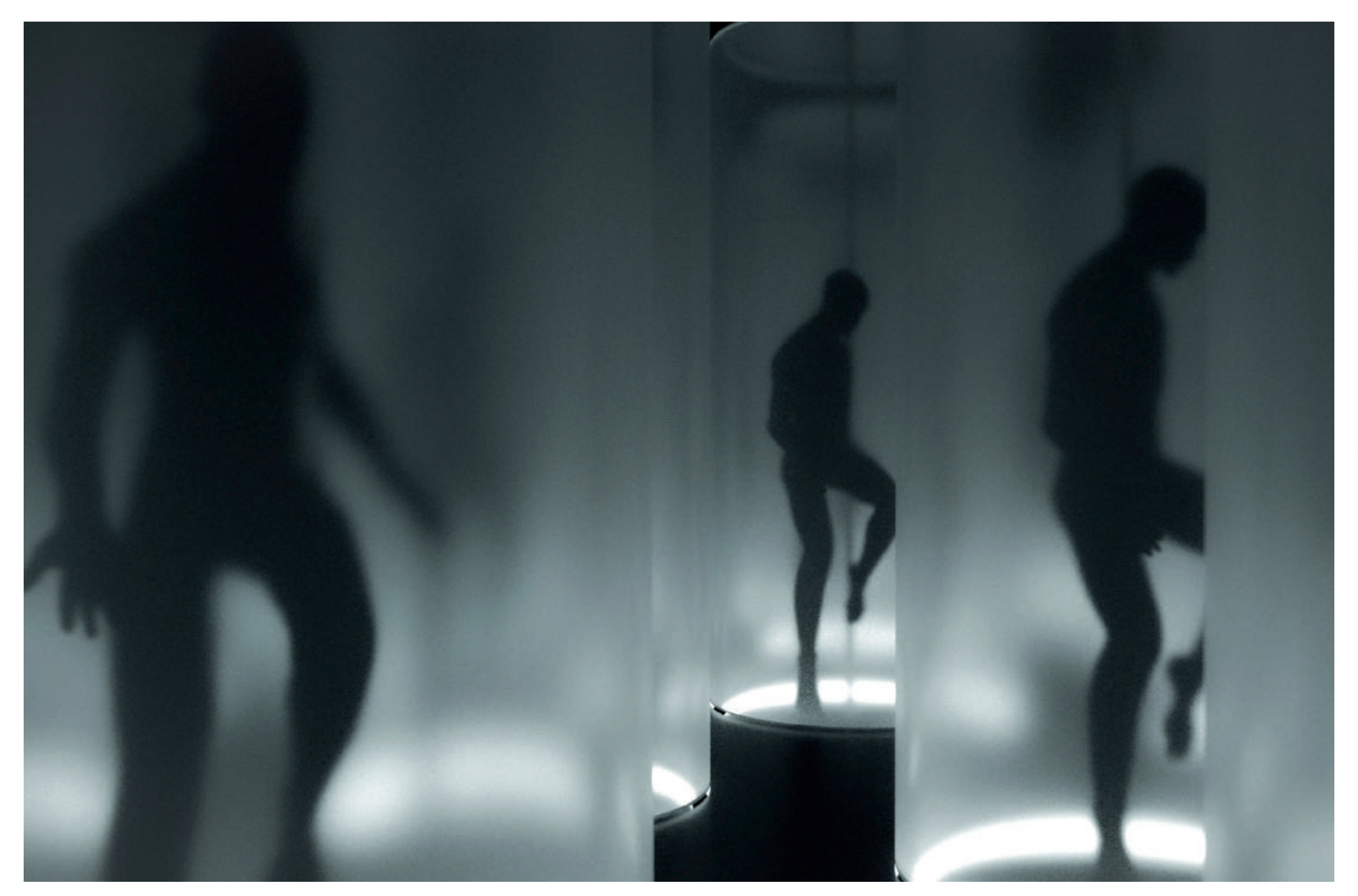

Post-Pandemic Sanatoriver

Post-Pandemic Sanatorium is a healing
space through a revamp adaptation for

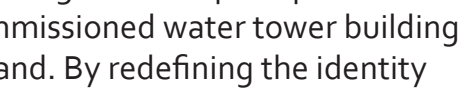

lestablished amysticicl tal
a post-pandemic narrative

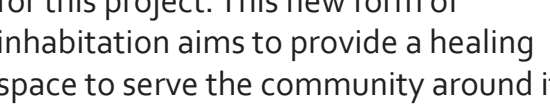

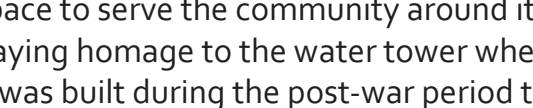

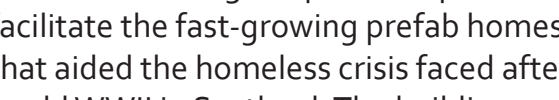

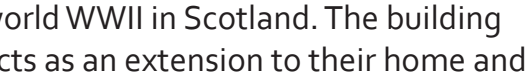

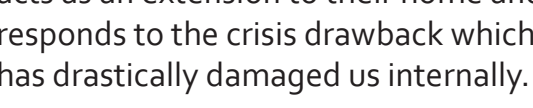

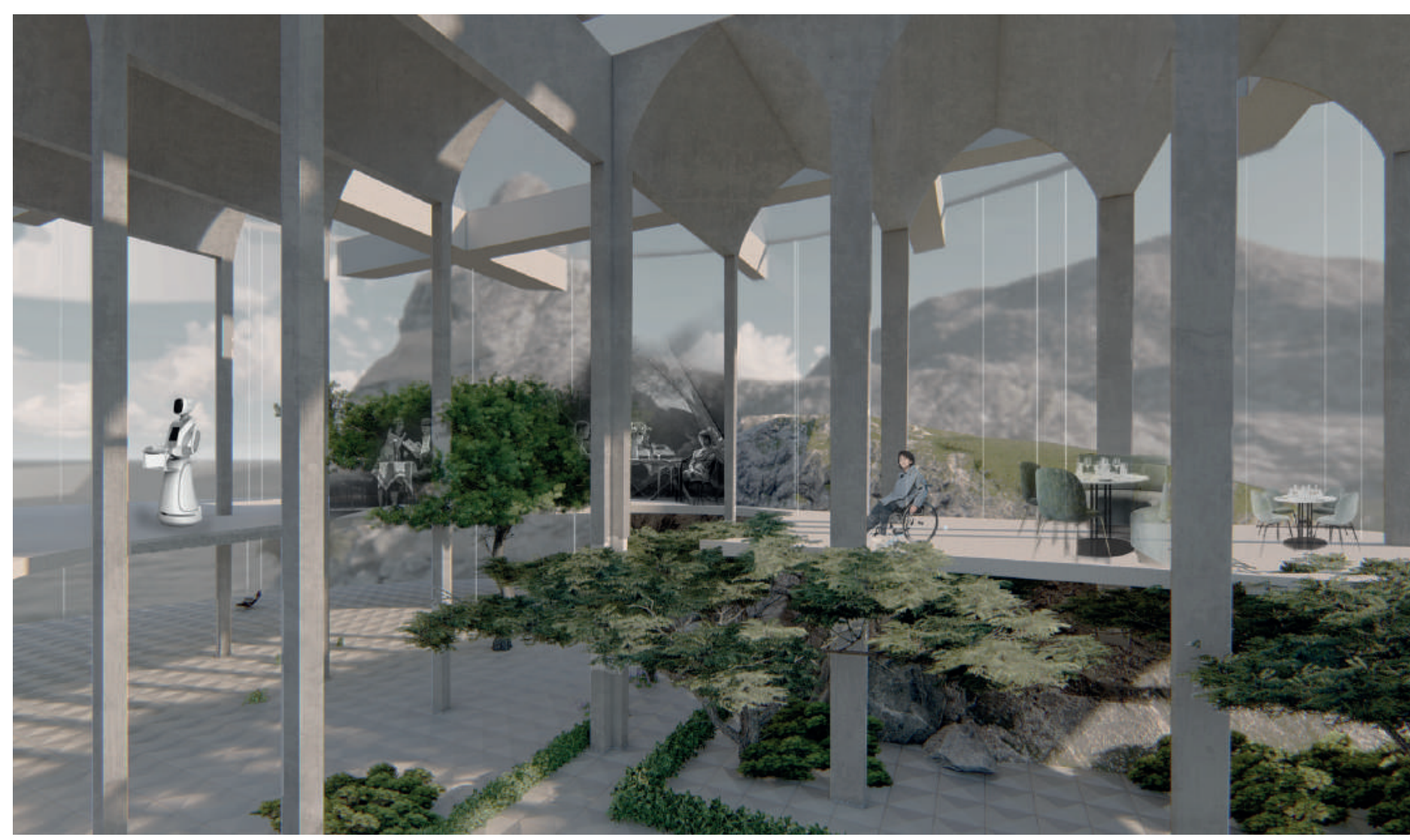

cyborg Hospital

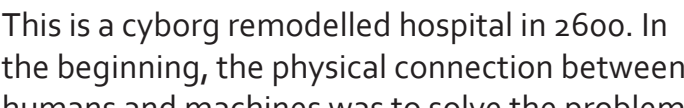

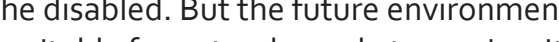

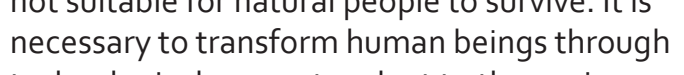

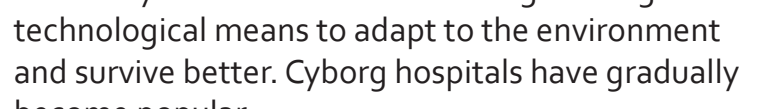

In the hosititaldesign, natural lemenents are

the boundary. Thisis is metaphor. In this prococess

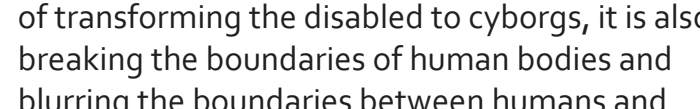

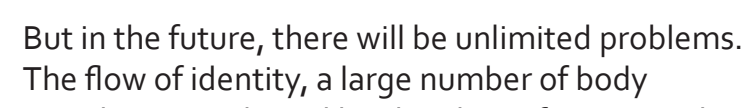

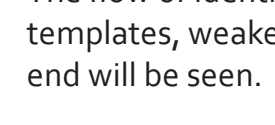

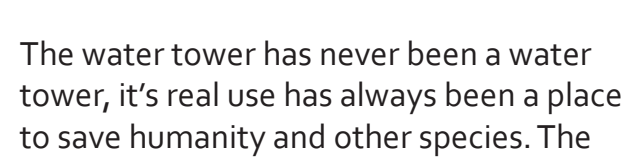

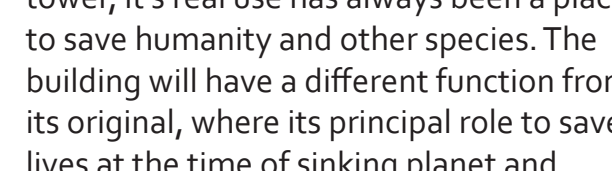

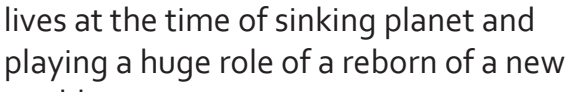

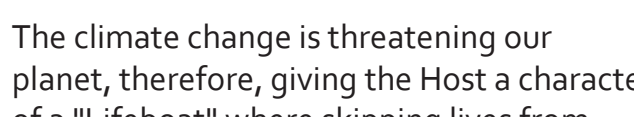

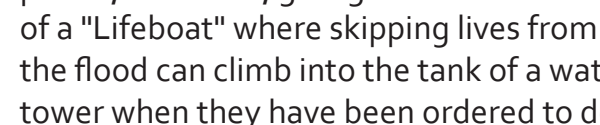

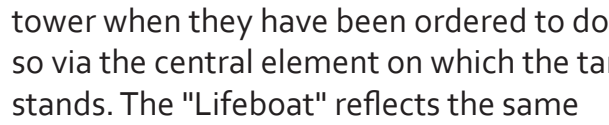

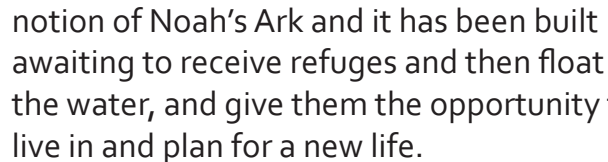

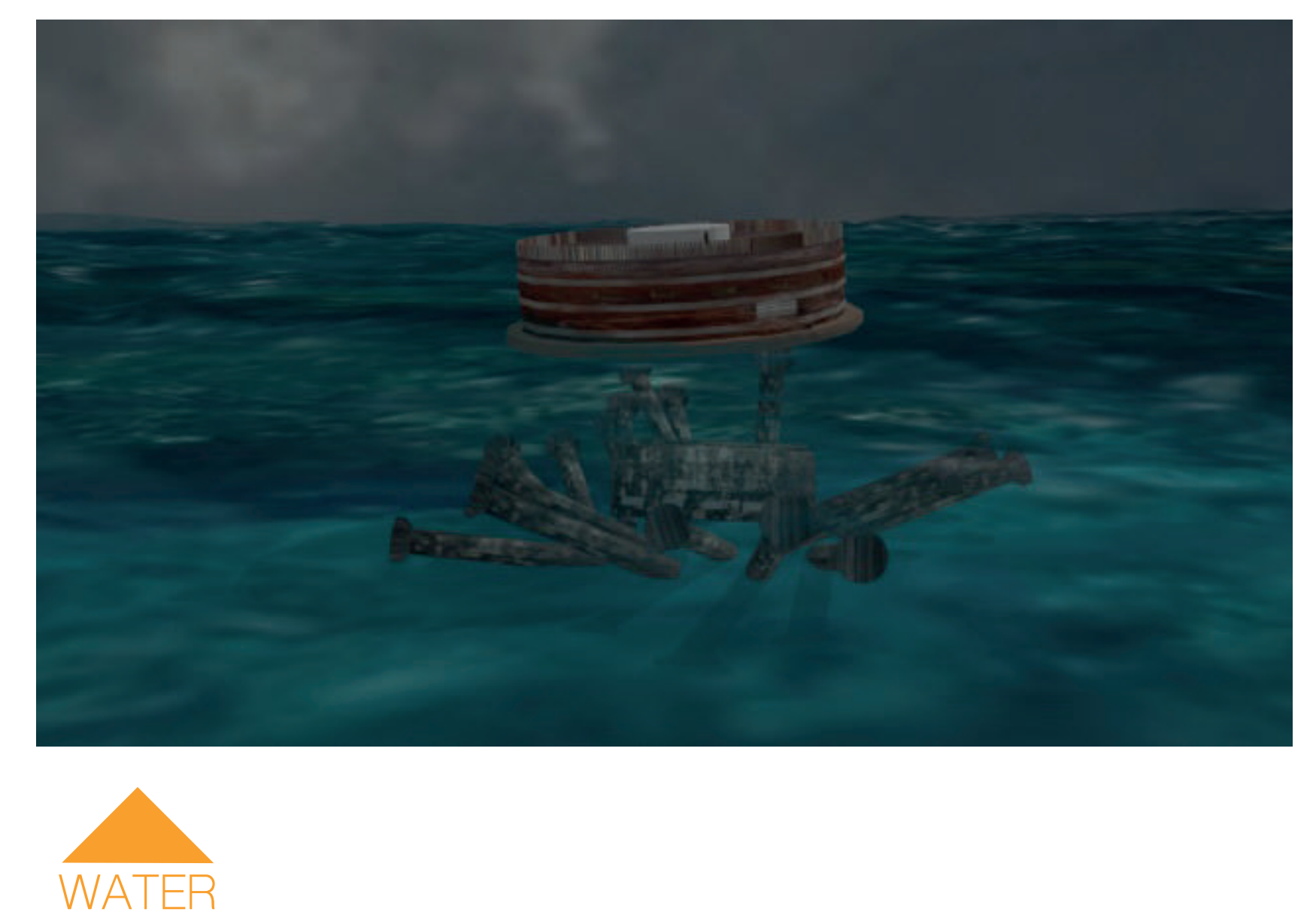

'New Memory' Community Centre
by Wenhan Li

My building is a water tower, which
is located in an abandoned meat

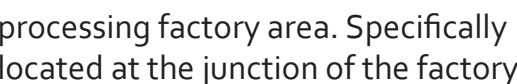

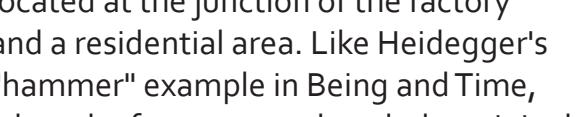

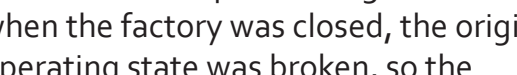

Workers oticed this State and began
buses

time went by, abandornment became the

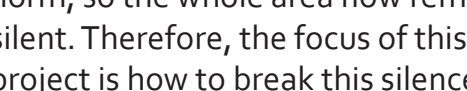

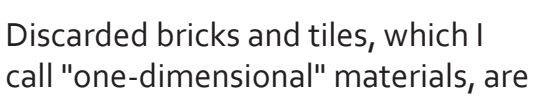

wall. With the increaese of fthe matererid

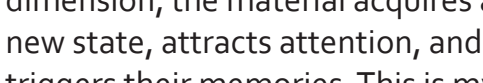

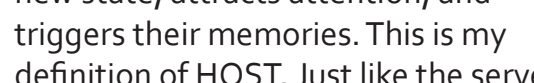

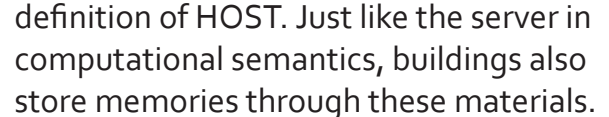

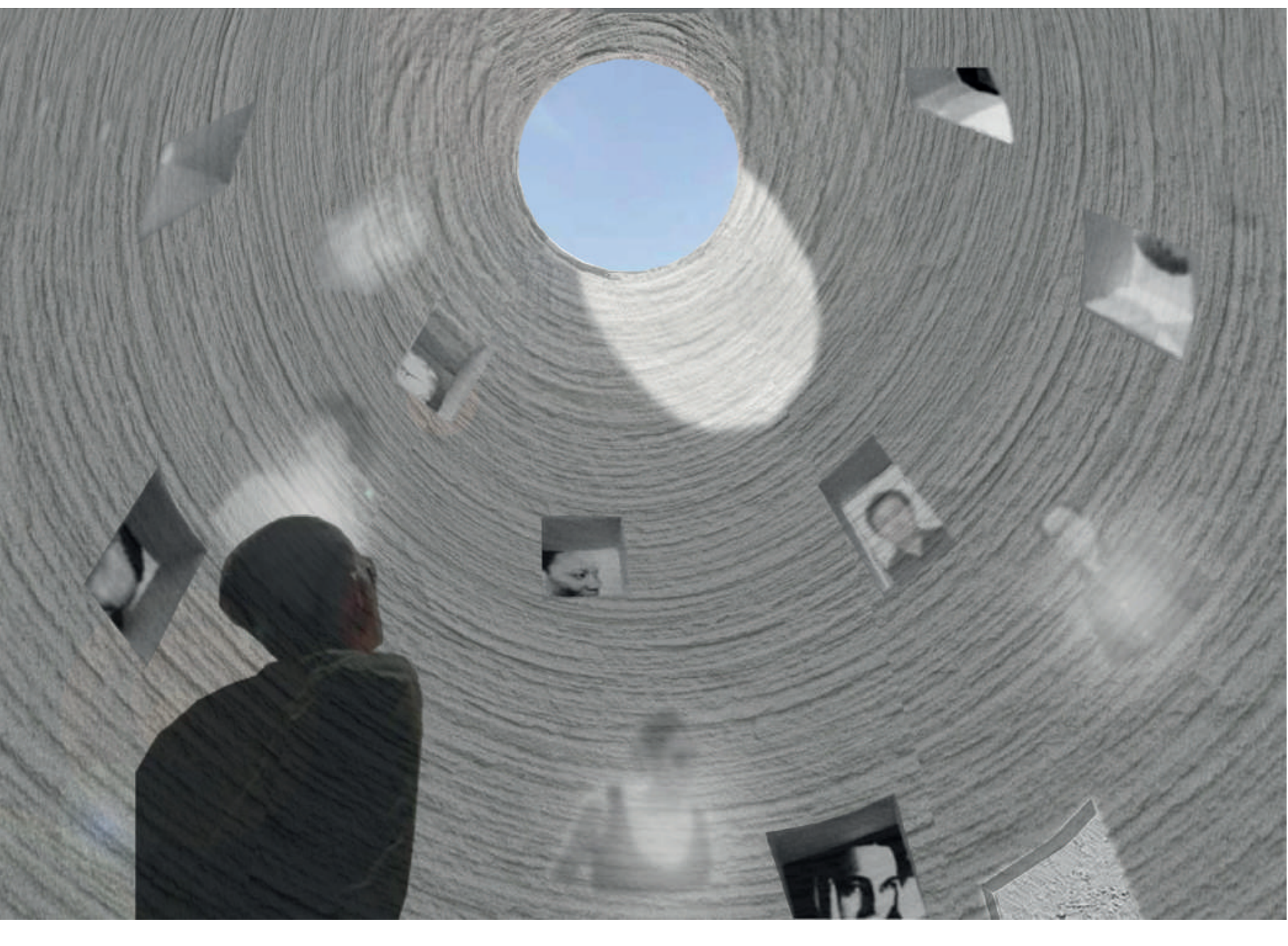

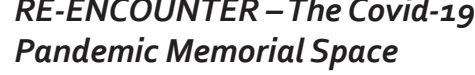

Chechut liang

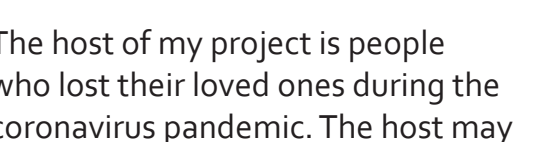

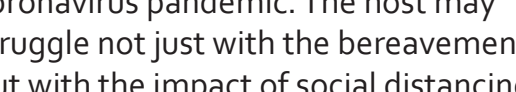

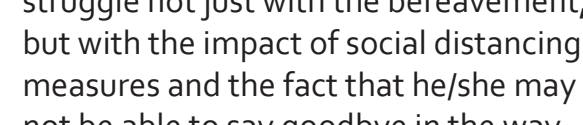

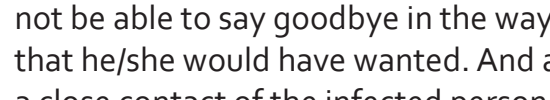

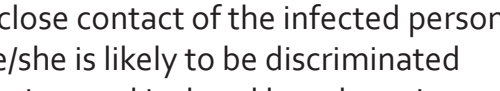

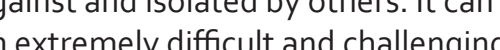

Me

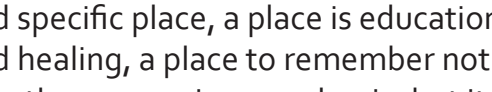

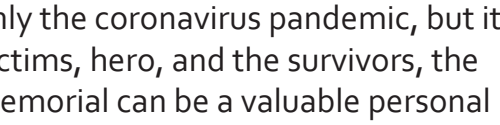

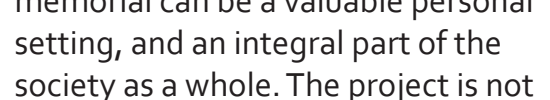

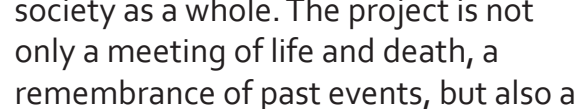

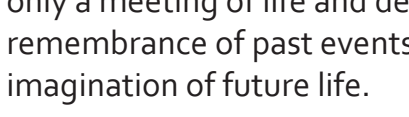




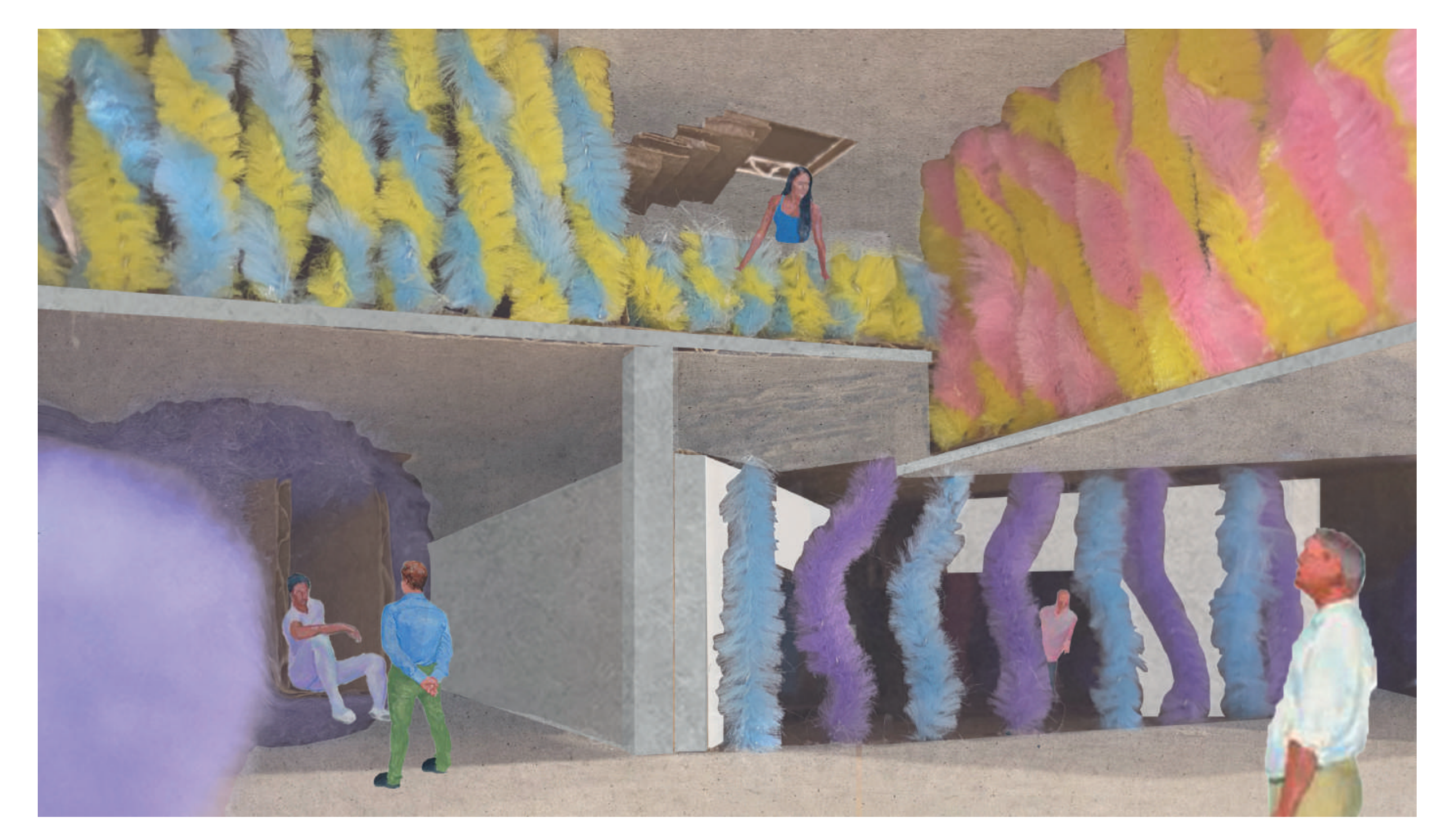

" 2 "ISLAND - A journey of queer gender

exploration
by Shanshan Jiang

Todady we livi in a world of fuality
where everything has an oposing side,

ight and wrong, black and white, yin
and yang, male eand female. 0 . on the

contraral, do people ever remember that
there is non-dualistic group of people

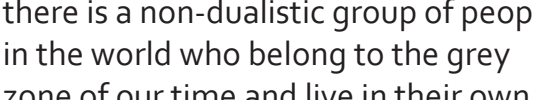

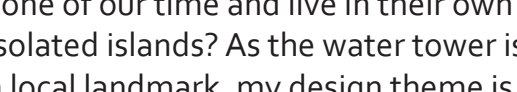

to break through the binary world and

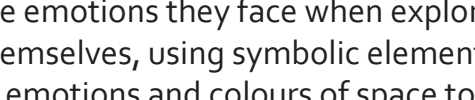

Demotiton and colours of space to
present then, while allowing the world
wunderstand and feel and reflect on the

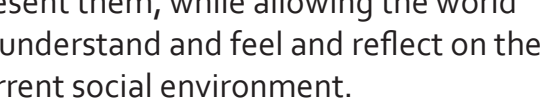

THE ONE
by Mengyu Jiac
The

The modern vision of the future city is based on reality. In the highly
developed

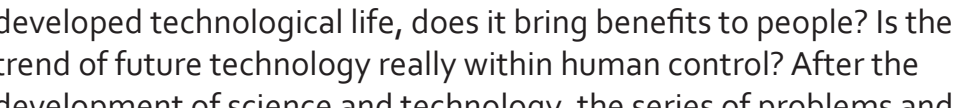

consequences that have arisen are worth of reffection.
The first stage is the investigation and andy

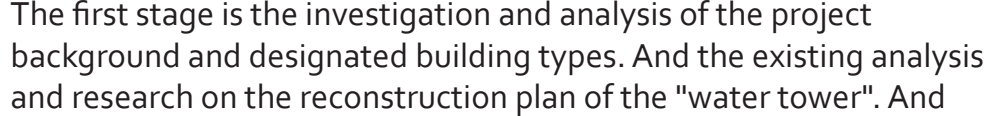

define the identity and concept of "Host"."The second stage is site

selection and initial space attempts. II tis particularly important to select
the location of the "water towert" and the relevannce to the "host" after"

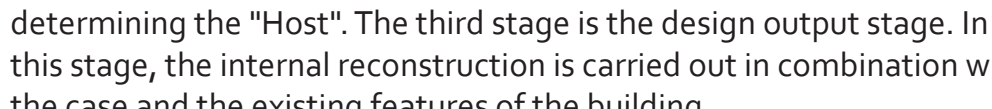

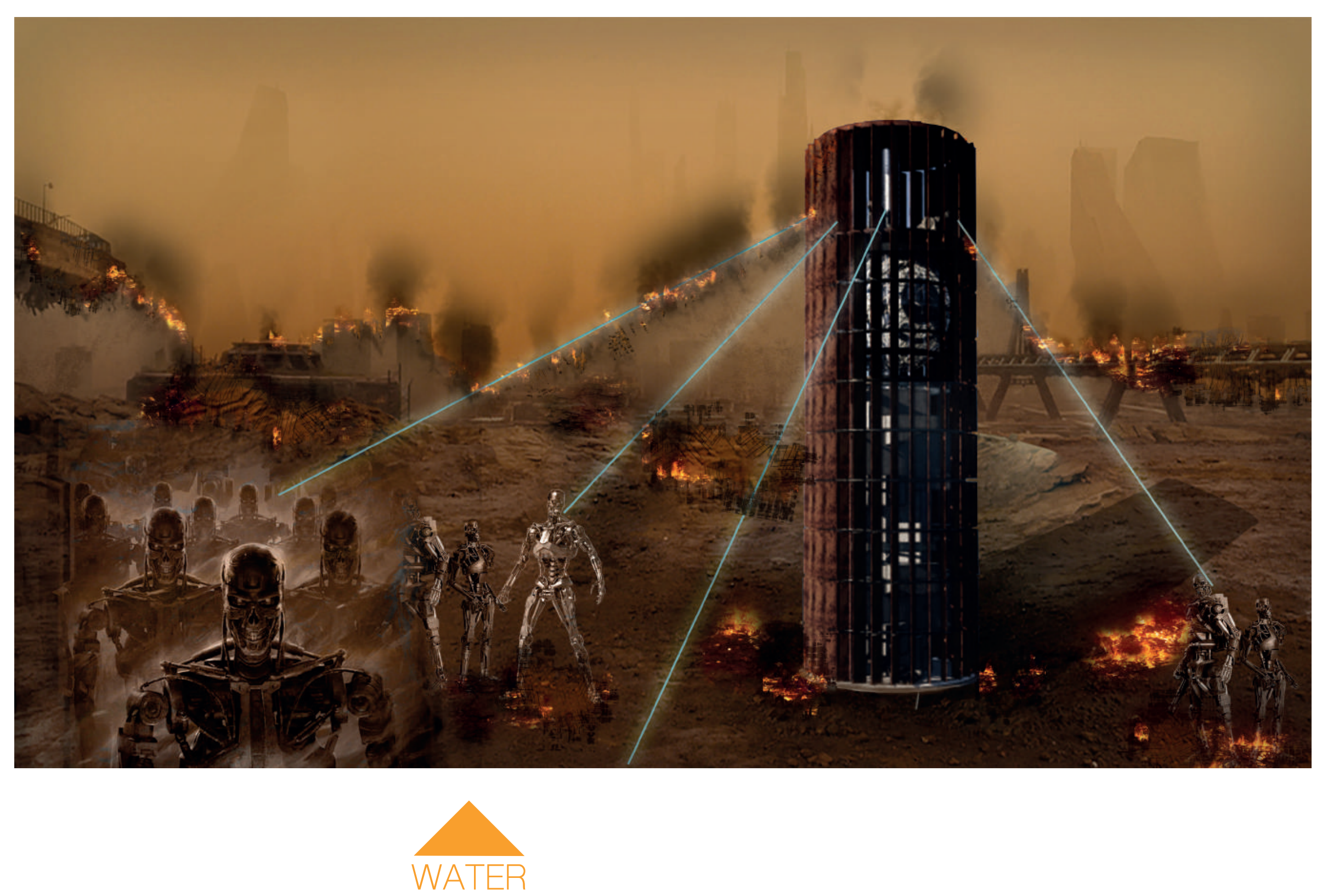

\begin{tabular}{|c|c|}
\hline $\begin{array}{l}\text { Innhabititing Infrastructure is an exhibition } \\
\text { and reseacr publication presenting a }\end{array}$ & $\begin{array}{l}\text { Masters of Interio } \\
\text { Design 2020-21 }\end{array}$ \\
\hline 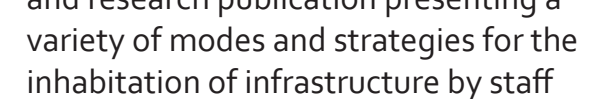 & \\
\hline $\begin{array}{l}\text { and postgraduate students from the } \\
\text { Interior Design Department at } \\
\text { The Glassogow School of Art }\end{array}$ & $\begin{array}{l}\text { Lyes Chikhoun } \\
\text { Shuyuan Deng } \\
\text { Wenfei Gao }\end{array}$ \\
\hline $\begin{array}{l}\text { Exhibitition and publication curated and } \\
\text { designed by Dove Loder } \\
\text { Part of A Archititecture ringe } 2021\end{array}$ & $\begin{array}{l}\text { Simrancusple } \\
\text { Shansan liang } \\
\text { Mengyv Jiao } \\
\text { Wenhan Li }\end{array}$ \\
\hline $\begin{array}{l}\text { All images copyright their respective } \\
\text { authors }\end{array}$ & $\begin{array}{l}\text { NatchaLang } \\
\text { Cunchuliang } \\
\text { Yun Liv }\end{array}$ \\
\hline Interior Design Department & $\begin{array}{l}\text { Erin Moodie } \\
\text { EnOian }\end{array}$ \\
\hline $\begin{array}{l}\text { Patrick Macklin (Head of Department) } \\
\text { Melba Beetham } \\
\text { Dave Loder } \\
\text { Digger Nutter } \\
\text { Jessica Oag-Cooper } \\
\text { Thomai Pnevrnonidou }\end{array}$ & $\begin{array}{l}\text { David Ross } \\
\text { Yang Shi } \\
\text { Ruby South Moffal } \\
\text { Wonder Wang } \\
\text { Unique Xia } \\
\text { Yijun Xing } \\
\text { WeiYan }\end{array}$ \\
\hline $\begin{array}{l}\text { The Glasgow School of Art } \\
167 \text { Renfrew Street } \\
\text { Glassow } \\
G_{3} 6 R Q\end{array}$ & $\begin{array}{l}\text { Ceiveivang } \\
\text { Xinvu } \\
\text { Jenyy } \\
\text { Mengzhang } \\
\text { Meng Zhang }\end{array}$ \\
\hline $\begin{array}{l}\text { Wuwwidgsa.co.uk } \\
\text { Quddgsa }\end{array}$ & $\begin{array}{l}\text { Xinyu Znao } \\
\text { Zhihan Zhao }\end{array}$ \\
\hline
\end{tabular}

- ARCHITECTURE

THE GEASGOW

SCHOOL: O ARt 


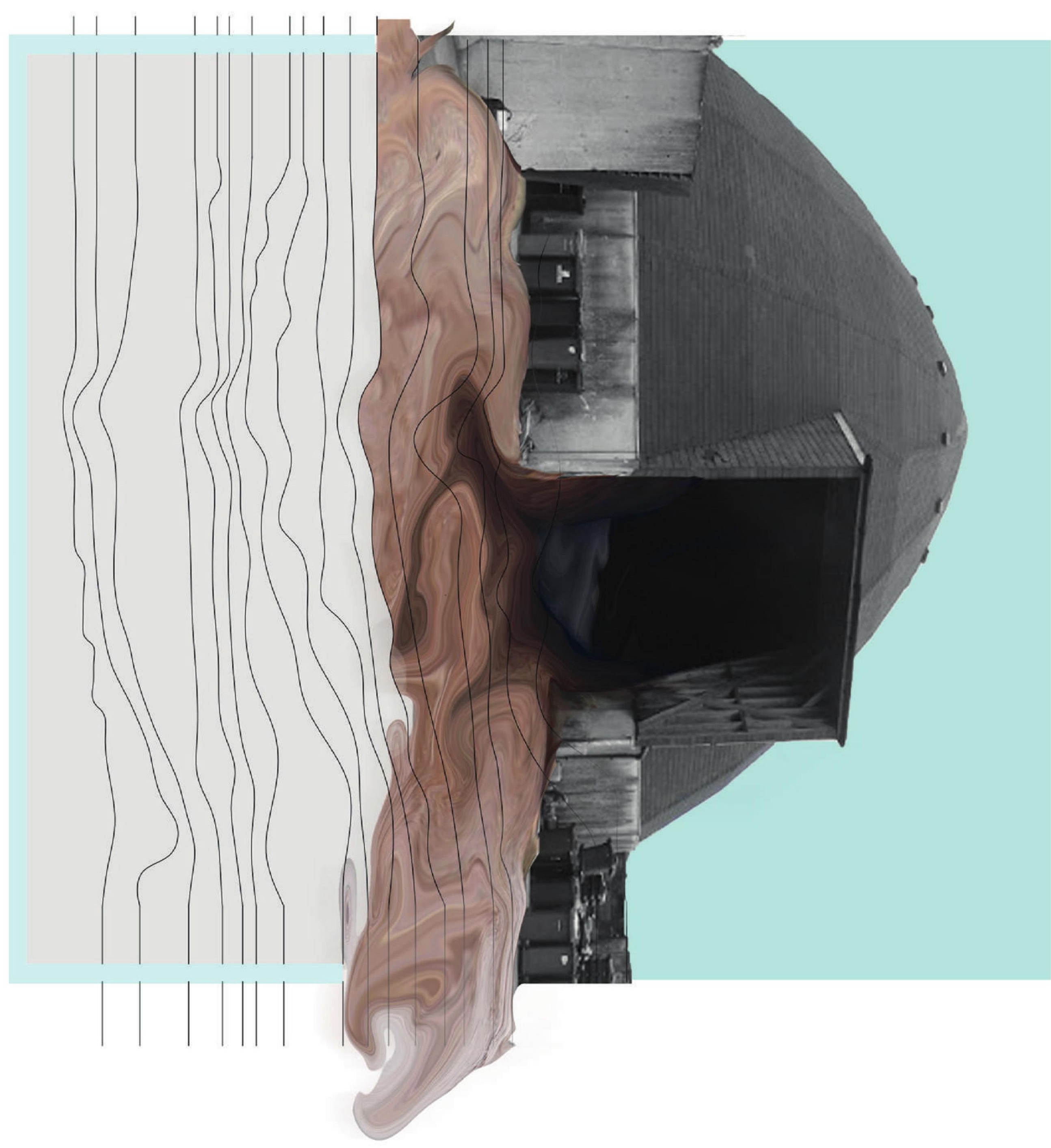

